\title{
Long-run Effects of Public Expenditure on Poverty*
}

\author{
Marisa Hidalgo-Hidalgo $\quad$ Iñigo Iturbe-Ormaetxe ${ }^{\ddagger}$
}

September 2017

\begin{abstract}
Household characteristics may have long-run effects on individual outcomes in adulthood. For instance, individuals who lived when young in households experiencing financial problems are more likely to be poor when adults. Governments try to reduce these effects and to promote equality of opportunity. The objective of this paper is to check whether public expenditure has a long-run effect in reducing the probability of being poor when adult, and to what extent. Our main finding is that public expenditure on education has a strong long-run effect on reducing incidence of poverty in adulthood. We also find that this effect is concentrated mainly among individuals who have parents with a low level of education.
\end{abstract}

Keywords: Public expenditure on education, poverty rate, intergenerational transmission of poverty

JEL Classification: H52, I21, I23, J24, J31.

${ }^{*}$ We thank Pedro Albarrán, M. Dolores Collado, Laura Crespo and Christophe Muller for helpful comments. We thank participants at Fifth ECINEQ Meeting, 2013 ASSET Meeting, XXXIII Simposio de Análisis Económico and Universitat de les Illes Balears. Marisa would like to thank CREST Paris, where part of this research was carried out, for their hospitality. Financial support from Ministerio de Economía y Competitividad (ECO2014-57413, ECO2012-34928 and ECO2015-65820-P (MINECO/FEDER)), Generalitat Valenciana (Prometeo/2013/037), Junta de Andalucía (SEJ-4941, SEJ-5980) and Instituto Valenciano de Investigaciones Económicas (IVIE) is gratefully acknowledged.

${ }^{\dagger}$ Address for correspondence: M. Hidalgo Hidalgo, Departamento de Economía (Area de Análisis Económico), Universidad Pablo de Olavide, Ctra. Utrera, Km.1, E-41013, Sevilla, Spain, mhidalgo@upo.es

${ }_{\ddagger}^{\ddagger}$. Iturbe-Ormaetxe, Universidad de Alicante, Alicante, Spain, iturbe@ua.es 


\section{Introduction}

There is a growing literature documenting how inequality has increased during the last decades in many developed countries (see Piketty, 2014 or Atkinson, 2010 for the EU; Atkinson et al., 2011 or Jenkins et al., 2013 for the US). For instance, in most OECD countries the gap between the rich and the poor has widened continuously prior to 2008 (OECD, 2011). In addition, recent OECD data (OECD, 2013) show that the global economic crisis has reduced incomes in most countries. However, this reduction is not shared evenly across the two extremes of the income distribution as there are larger reductions at the bottom part of the distribution. This fact suggests further increases in inequality and poverty. It is also well-known that living in poverty during childhood has long-run negative effects. Children from poor families are more likely to be poor when adults, are also more prone to suffer health problems, and are less likely to stay in school after the end of compulsory education (see Corak, 2006 or Jenkins and Siedler, 2007 and references therein). These long-run effects reflect the degree of intergenerational mobility in a society. In countries where social mobility is low, being poor when young is a good predictor of the probability of being poor when adult.

There are at least two plausible mechanisms underlying the intergenerational transmission of poverty. First, there may be genetic differences in ability that are transmitted from parents to children, leading to intergenerational persistence in poverty. Second, rich parents invest more in the human capital of their children, who end up with more education. This second mechanism suggests a role for government intervention to equalize opportunities. In particular, public intervention at early stages is seen as one of the most important tools to reduce the long-run effects of poverty and to promote equality of opportunity.

Our objective is to estimate the effects of public expenditure on poverty status in adulthood in Europe. The notion of poverty used is income-based, reflecting the main approach in the literature. ${ }^{1}$ In order to do so, we combine individual and aggregate variables by merging data from the 2005 and 2011 cross sections of the European Union Statistics on Income and Living Conditions (EU-SILC) with data on public expenditure that we retrieve from the United Nations Educational, Scientific and Cultural Organization (UNESCO) database. The 2005 and 2011 cross sections of EU-SILC include a special module on "Intergenerational transmission of poverty." The database we construct allow us to analyze which factors con-

\footnotetext{
${ }^{1}$ As measures of social exclusion, material deprivation and material hardship are becoming more and more available, the concept of multidimensional poverty is increasingly used. For instance, Figari (2012) analyses the relationship between deprivation, income and other individual dimensions over time, in eleven European countries. For an overview of this literature see Morelli et al. (2015) or Nolan and Marx (2009).
} 
tribute to cross-country and cohort differences in the probability of falling below the poverty line.

Ideally, we would like to have data on all categories of public expenditure, in particular those items that can be categorized as expenditure in children. We would also need data on public expenditure covering a period of time as long as possible. These two requirements lead us to use data on public spending dedicated to education. In particular, we have data on public education spending since 1971 that are disaggregated at three levels (primary, secondary, tertiary) for a number of European countries. This could be seen as a potential drawback of our approach, since any effect that we may find of public expenditure on adult poverty status could be attributable not to spending in education per se, but to public spending in general. However, in a previous work Mayer and Lopoo (2008) study the long run effect of public spending on intergenerational income mobility in the USA. They find that intergenerational mobility is greater in high-spending states, compared to low-spending states. Interestingly, when they disaggregate by categories of spending they find that spending on primary and secondary education is the public spending that has the largest impact on lowincome children's future income. Regarding the period of time for which we have available data on spending, the oldest data go back to 1971, allowing us to consider individuals born from 1954 and later. We follow an approach similar to that of Mayer and Lopoo (2008) and try several definitions of per capita expenditure to capture the level of public investment per individual. First, we assign to each individual average expenditure per pupil at the three levels when the individual was between the ages of 15 and 17. Next, we consider other more restrictive definitions as the sum of expenditure per pupil only in primary and secondary education, and the expenditure at each level separately.

The first result we get is that expenditure on primary and secondary education seem to have a strong long-run effect on reducing the incidence of poverty in adulthood. As an illustration, an increase of one standard deviation in expenditure on secondary education is associated with a reduction of 0.61 percentage points in adult poverty, which is an important reduction as it represents $5 \%$ of the mean poverty rate (12.11). This association between public expenditure and poverty vanishes when we consider expenditure in tertiary education. Next, we compute the effects of expenditure for different sub-groups of individuals according to the characteristics of the family in which they were raised. In particular, we divide individuals into two groups depending on the level of education of their parents. Our second result is that the beneficial effect of public expenditure on education is concentrated mostly among individuals with low-educated parents. This result holds for most of the models we estimate. For instance, an increase in expenditure in secondary education of the size of one 
standard deviation is associated with a reduction of 1.24 percentage points in the incidence of poverty in adulthood for children from low-educated families. At the same time, we find that expenditure is positively associated with adult poverty for individuals from educated families. This result underscores that the effects of public expenditure are coming through individuals whose parents had low levels of education. A likely implication is that public expenditure helps to increase intergenerational mobility.

The effects we have obtained can be explained by a simple human capital model in which individuals' outcomes today are a function of both their own endowments and of human capital investments received while young. For instance, an increase in public expenditure may push some individuals to undertake post-compulsory education. This, in turn, may reduce the probability of being below the poverty line in adulthood. There are several works documenting a positive effect of education spending on later outcomes. Some studies find a positive effects on test scores (see Hedges et al., 1992) whereas others do not find a significant impact (see Hanushek, 1996, 2001). Grogger (1996) finds that state per-pupil spending on compulsory education is associated with higher post-schooling wages. Within this literature, there are other authors who use alternative identification strategies. For example, Meghir and Palme (2005) evaluate the impact of a school reform that took place in the 1950s in Sweden on educational attainment and earnings. This reform consisted of increasing compulsory schooling, among other aspects, and thus can be seen as an increase in per capita public expenditure on education. They find that this reform increased both educational attainment and earnings of those individuals whose fathers had only compulsory education.

Our identification strategy to assess the impact of government spending on individual's poverty status consists of exploiting country and time variation in expenditure. We identify the effect of public intervention by exploiting changes in spending across countries from the initial period in our sample. As different countries experience different economic situations that might have different effects on different cohorts, we also control for other country-cohort variables, such as per capita GDP and income inequality during childhood. However, there are many other factors that may have changed within particular countries between the time the individual was a teenager and the expenditure was made and the moment when poverty status is determined. To address this problem, we include the change in per capita GDP and the change in our measure of inequality from the time the individual was 15-17 until the year of survey response, respectively. These two additional variables capture country-specific time trends. Finally, we perform a number of robustness checks. In particular, we check the validity of our results to alternative measures of parental circumstances and current poverty status and to alternative specifications of the model. We also implemented a falsification 
exercise for the exposure to public expenditure.

The paper is related to the literature that studies the long-run effects of government spending on adult outcomes as income or poverty. The most closely related papers to ours are Mayer and Lopoo (2008), mentioned above, and Jackson et al. (2016). The former assesses the relationship between government spending and intergenerational economic mobility using PSID data together with data on state spending from the U.S. Census of Governments. The latter also uses U.S. data and finds a significant effect of increased school spending on children from poor families. In particular, they find that an increase of $10 \%$ in expenditure for all years of K-12 education reduces the incidence of adult poverty by 3.2 percentage points.

In addition to public expenditure, the previous literature has shown that individuals' socioeconomic background is also a crucial determinant of adult poverty. There is substantial evidence that poverty is to a large extent inherited across generations. Recently, Bellani and Bia (2016) using also data from EU-SILC 2005 and 2011 find that exposure to poverty in childhood reduces equivalized income in adulthood by about $5 \%$ and increases the probability of falling below the poverty threshold by about 6 percentage points. For a review of this literature, see Jäntti and Jenkins (2014). While experiencing financial problems during childhood is shown to have a strong impact on poverty in adulthood, other dimensions of family background, as parental education, are associated with future poverty. For example, Corcoran and Adams (1997) were among the first who attempted to separate the impact of poverty during childhood from other family background characteristics (such as parental schooling). Blanden and Gregg (2004) perform a similar study. Both studies found that individuals with better educated parents are less likely to be poor themselves. Hertz et al. (2007) report strong correlations between schooling of parents and children for many countries. Holmlund et al. (2011) provide a survey on the different methodologies used to study the causal effect of parent's schooling on children's schooling. Recently, Piopiunik (2014) suggests that the channel for this relationship could be that parents with more education value good school performance of their children more highly and are more likely to believe that schooling is good for them. Finally, see Marx et al. (2014) for a recent survey of these types of studies. In this paper, we control for the role of parental background while studying the long-run effect of public expenditure on adult poverty.

Our paper contributes to the literature in several respects. First, we focus on intergenerational poverty transmission rather than on transmission of income, as most of this literature does. Surprisingly, there is almost no evidence on the potential mitigating effect of public expenditure on poverty, despite the recent trends in poverty and income inequality. Second, we focus on a group of European countries using data from the EU-SILC. Finally, we also 
add to this debate by using a more narrowly defined measure of expenditure on children's schooling.

The paper is organized as follows. Section 2 describes the data used in the paper. Section 3 presents the empirical model. We discuss our empirical results in Section 4. Finally, Section 5 concludes.

\section{Data and descriptive statistics}

Estimating whether government expenditure has a long-term effect on reducing poverty requires individual-level data on adult's income together with information on the characteristics of the household where that adult grew up. It also requires a source of variation in government expenditure. In this study, we merge data drawn from both the 2005 and 2011 cross sections of the EU-SILC database with data from the UNESCO database for Education. We build a database comprising 16 European countries. These are the countries in the EU-SILC database for which we have enough historical data on public expenditure. ${ }^{2}$

The reason for using the 2005 and 2011 cross sections of the EU-SILC database is that they include special modules on intergenerational transmission of poverty. ${ }^{3}$ Using these modules requires one to exclude from the 2005 and 2011 cross sections all individuals who are not in the age range of the module (25-65) and are not the selected respondent. These modules contain retrospective information on parental background and childhood circumstances including, in particular, family composition, year of birth of parents, occupation, and level of education of parents. To assess the long-run effect of household characteristics, we exclude all individuals who lived in a collective house or in some institution when young. Individuals also provide retrospective information about the socio-economic situation of the household they lived in when teenagers. All these variables give us valuable information on individual circumstances that prevailed before the end of compulsory education. Individuals report the highest level of education attained by their mother and their father. We summarize this information by building a dummy variable called "educated_family" that takes the value of 1 when either the mother or the father has at least secondary education. ${ }^{4}$ We have also explored the possibility of introducing parental education in several other manners (see the Online Appendix, Section

\footnotetext{
${ }^{2}$ The list of countries is: Austria, Belgium, Denmark, Finland, France, Greece, Hungary, Ireland, Italy, Luxembourg, Netherlands, Norway, Portugal, Spain, Sweden and United Kingdom.

${ }^{3}$ For an overview of EU-SILC, see Wolff et al. (2010). To access further information about EU's regulations concerning the SILC, data documentation provided by Eurostat, and SILC variable lists, we recommend the EU-SILC web portal provided by the GESIS research institute at http://www.gesis.org/.

${ }^{4}$ The mean value of educated-family is .355 (st. dev. is .478). Requiring tertiary education would be too restrictive, since only a $11.68 \%$ of individuals in the sample have at least one parent with tertiary education.
} 
A). As can be observed there, our main results do not depend on how parental education is defined. In addition to parental education, we consider a set of household characteristics when the individual was young (unemployed father, number of siblings, single mother family, etc.). ${ }^{5}$ See Section $\mathrm{F}$ in the Online Appendix where we check the validity of our results to alternative measures of childhood circumstances.

As we said above, we obtain data on public expenditure from the UNESCO Database for Education. The UNESCO Database for Education contains country data on annual public expenditure in education per student going back to 1971, although in some countries there are missing data for some years. The original data correspond to percentages of per capita GDP at three levels (primary, secondary, tertiary). We use data on per capita GDP to recover data on expenditure in primary, secondary and tertiary education for each country and year. We also use data on Purchasing Power Parities from the World Bank. ${ }^{6}$ Since data on per capita GDP are in US dollars of year 2000, all our data on expenditure per individual have the same purchasing power in terms of 2000 US dollars. Our data cover the period from 1971 to 2008 , for which we have 608 distinct country-year cells. ${ }^{7}$

We propose different ways of measuring per child expenditure. We follow previous research on the long-run impact of public expenditure on adult circumstances using different combinations of per pupil public education expenditure as proxies of public expenditure. ${ }^{8}$ As we do not know whether they attended education in a different country, we exclude from our sample all individuals who were not born in the country of residence at the time of the survey

The first measure we consider aggregates expenditure across the three educational levels and takes the average of these expenditures for the country of residence when the child was of ages 15 to 17 . This allows us to study the effect of public expenditure made before the age at which individuals may join the labor market. We think of our measure as a proxy for general public expenditure rather than a measure of public expenditure in education. As an example, consider the case of an individual born in Spain in 1960, who was 16 in 1976. The sum of public spending per capita at the three levels in Spain in 1976 was $\$ 3,558.57$. The corresponding

\footnotetext{
${ }^{5}$ We do not use information on parents occupation, since these variables contain a large fraction of missing values.

${ }^{6}$ See http://www.uis.unesco.org/Education/Pages/default.aspx and http://data.worldbank.org/ for data on public expenditure in education and PPP, respectively.

${ }^{7}$ Since our sample contains 16 countries, in principle we could have data for the three educational levels corresponding to $16^{*} 38=608$ distinct country-year cells. However, we lack data corresponding to 115 of these cells. This can be due to the fact that UNESCO did not collect data every year in every country. We use a simple linear interpolation to smooth expenditure data. We cannot do this when missing data for a given country correspond to the first or the last years of the period considered. As an example, data for Belgium are only from 1975 onwards while for Spain they are from 1972.

${ }^{8}$ See Akin and Garfinkel (1980), Grogger (1996), or Mayer and Lopoo (2008).
} 
numbers for 1975 (when 15) and 1977 (when 17) are $\$ 3,415.94$ and $\$ 3,517.64$, respectively. We assign to this individual the average of these three numbers, namely $\$ 3,497.38$. By doing so, we get a smoother measure of expenditure than just considering expenditure at age 16 only, for instance. Our second measure is similar to the first one, but adds only expenditure for primary and secondary education. With this second measure, we try to capture expenditure at the compulsory levels of education, which could be a better measure of the level of public spending from which all individuals have benefitted. We also consider expenditure separately at each one of the three levels. By doing this, we try to see which one of the three components of government exhibits the strongest association with poverty reduction.

Observe that our measure of public expenditure is not the exact amount individuals received while they attended primary, secondary or tertiary education. In that case, and in particular regarding expenditure on tertiary education, the amount of public expenditure assigned to each individual would depend on his (endogenous) decision of college attendance, which is highly correlated with parental education (see, for example, Piopiunik, 2014 for recent evidence on the causal link between parents and children's education). Thus, by constructing our measure in this way, we avoid introducing bias on the impact of public expenditure on future poverty status. Since our oldest data on public spending go back to 1971, we have to restrict our sample to individuals born between 1954 and 1980 (for the 2005 cross section) and between 1954 and 1985 (for the 2011 cross section). ${ }^{9}$ This means that the age range in our sample varies between 25 and 57 . The reason to choose expenditure when individuals were 15-17 is to have the largest possible sample size. An individual born in 1954 was 17 in 1971, so we can assign to him/her some expenditure in that year. In addition, Mayer and Lopoo (2008) use the same age interval. Nevertheless, we redo the exercise considering public expenditure earlier in life. In particular, we choose expenditure when the individual was aged 10-12. Now the earliest cohort would be that of 1959, which implies we lose five birth cohorts (1954-1958) with a sizable reduction in sample size (see Table 5). Our results remain qualitatively the same, although, as we comment below, we lose significance in some models . Our final sample consists of 163,159 individuals from 16 countries. Of those, 78,183 are in the 2005 wave and 85,021 in the 2011 wave.

Our objective is to study whether public expenditure helps to mitigate the effects on adult circumstances of being raised in a disadvantaged household. In particular, we focus on individual's current poverty status. ${ }^{10}$ This is the information contained in the variable

\footnotetext{
${ }^{9}$ With our measure, for those born in 1954 we assign public spending in 1971 (they are 17 in 1971) only, while for those born in 1955 we assign the average of public spending in 1971 and 1972 (they are 16 and 17 , respectively).

${ }^{10}$ In Online Appendix, Section F, we perfom some robustness checks to alternative definitions of monetary
} 
HX080, which is an indicator of whether the individual lives in a family with income below the poverty threshold. ${ }^{11}$ We define a dummy variable called "poor" which is 1 whenever HX080 is 1 . This is a standard poverty measure and the official one in the European Union. ${ }^{12}$ The mean value of poor in our final sample is $12.11 \%$. It takes roughly the same value in both waves. Figure 1 shows the percentage of individuals below the poverty line in each country.

\section{Figure 1}

The maximum value is found in Greece (18.6\%) and the minimum in Denmark (3.6\%). The dotted line is the mean for the whole sample. It is important to remember that these numbers are not representative of the whole population, since we are considering only those individuals who at the time of the survey were $25-51$ in the 2005 wave or 25-57 in the 2011 wave. In particular, the elderly are excluded from our sample. Table 1 shows the main descriptive statistics. A complete description of all the variables we use can be found in the Appendix.

\section{Table 1}

Table 2 below illustrates the correlation between current poverty status and family background, as measured by parental education. We compute probabilities for the current poverty status (variable poor), conditional on the two possible values of the variable educated_family. We also provide their corresponding standard errors. We do it separately for the two cross sections and also pooling all the data. As Table 2 shows, there is a strong association between these two variables.

poverty, in particular considering other income sources.

${ }^{11}$ The poverty line corresponds to $60 \%$ of equivalized household disposable income and corresponds to the standard measure of poverty in the European Union. Equivalized household disposable income (HX090) is equal to the product of total disposable household income (HY020), multiplied by an inflation factor for within-household non-response (HY025), divided by equivalized household size (HX050). That is, HX090= $\frac{H Y 020 * H Y 025}{H X 050}$.

${ }^{12}$ See http://ec.europa.eu/eurostat/statistics-explained/index.php/Glossary:At-risk-of-poverty_rate 
Table 2: Long-run effects of parental education

\begin{tabular}{lrlrlrrr} 
& \multicolumn{2}{c}{ Poor 2005 } & \multicolumn{2}{c}{ Poor 2011 } & \multicolumn{2}{c}{ Poor All } \\
\hline \hline & Mean & SE & Mean & SE & Mean & SE \\
\hline educated_family=0 & 15.04 & 0.16 & 15.37 & 0.16 & 15.21 & 0.11 \\
educated_family $=1$ & 6.14 & 0.15 & 6.59 & 0.14 & 6.40 & 0.10 \\
Difference test $p$-value & $<0.0001$ & & $<0.0001$ & & $<0.0001$ & \\
All & 12.11 & 0.11 & 12.11 & 0.11 & 12.11 & 0.08 \\
\hline \hline
\end{tabular}

In the 2005 cross section (Column 1 in the table), the proportion of individuals who had low-educated parents that are below the poverty line is $15.04 \%$. However, for those individuals with educated parents this probability is just $6.14 \%$. We find similar differences in the 2011 cross section ( $15.37 \%$ vs. $6.59 \%)$ and with the two cross sections combined $(15.21 \%$ vs. $6.40 \%$ ). So, roughly speaking, the probability of being below the poverty line for individuals with low-educated parents is twice as big as that of individuals with highly-educated parents. ${ }^{13}$ We illustrate these correlations at the country level in the online Appendix, Section B.

Finally, we briefly describe the connection at the country level between expenditure and poverty by family type. In order to do so, we compute poverty rates according to the education of parents for each country. We use the average value of one of our measures of spending per individual (in logs), in particular our first measure of public expenditure that aggregates expenditure across the three educational levels (primary, secondary and tertiary) for the country of residence when the child was of ages 15 to 17. As we have already seen in Table 2, poverty rates are typically higher among individuals with low-educated parents. Figure 2 shows poverty rates for these two groups as a function of average public expenditure. We fit a line for each group. We see that higher expenditure is associated with lower poverty rates mostly for individuals whose parents have a low education level. ${ }^{14}$

Figure 2

Next, we analyze whether these relationships observed at the country level hold also at the individual level.

\footnotetext{
${ }^{13}$ The t-statistics for the difference in mean poverty between individuals without educated parents and with educated parents are equal to 35.96, 41.13 and 54.54 for the 2005, 2011 and the all sample respectively.

${ }^{14}$ The slope of the line corresponding to individuals with parents with low education is -.085 (p-value 0.004), while the one corresponding to individuals with highly educated parents is -.013 (p-value 0.228).
} 


\section{Empirical model}

Our aim is to study the effect that public expenditure has on reducing the long-run negative effects of having a disadvantaged background. The relationship of interest between public expenditure and poverty status is given by the following equation:

$$
\operatorname{POOR}_{i}=\beta_{0}+\beta_{1} P E_{c t}+\beta_{2} E D_{-} F A M_{i}+\beta_{3}\left(P E_{c t} \times E D_{-} F A M_{i}\right)+X_{i} \gamma+\beta_{c}+\beta_{t}+\varepsilon_{i}
$$

where $P O O R_{i}$ is an indicator that equals 1 if individual $i$ lives in a household that has disposable income below the poverty line. The variable $P E_{c t}$ is the logarithm of our measure of public spending per capita corresponding to an individual from country $c$ born in year $t .^{15}$ We try different measures of public spending, as described above. The variable $E D_{-} F A M_{i}$ is a dummy variable capturing parental education. We add an interaction term of this dummy variable with public expenditure to test whether individuals who grew up in families in which both parents had little education benefit differently from public expenditure, compared to other individuals. We include country fixed effects in the model, captured by the term $\beta_{c}$ which contains a set of dummy variables, to control for invariant factors within countries. We include a time trend, captured by the parameter $\beta_{t}$ that represents a vector of birth year variables. In particular, it addresses a possible common time trend toward increasing public expenditure. Because of the structure of our data, we cannot include country-specific time trends since these ones would be perfectly correlated with our measures of public expenditure. Recall that we assign the same value of expenditure to all individuals who were born in the same year and country. However, below we include two additional regressors that help to capture country-specific time trends.

The vector $X_{i}$ contains the remaining explanatory variables, apart from parents' education. First, there are variables describing current circumstances (gender, non-citizen status, date of survey). Second, we include a set of family background variables that were determined well before schooling was completed. We include number of siblings, having been raised in a single-mother family and whether the father was unemployed at that time. Third, we add some country-cohort specific variables. In particular, we control for per capita GDP at the time the individual benefitted from each particular measure of $P E$. By doing so, we relate

\footnotetext{
${ }^{15}$ We could alternatively consider the ratio of expenditure over GDP as our main regressor of interest (see Hidalgo-Hidalgo and Iturbe-Ormaetxe (2013) for a similar strategy). However, we choose our approach for two reasons. First, it is a more general specification (observe that using the ratio implies restricting the effect of $\ln (G D P)$ to be the mirror effect of $\ln (P E))$. Second, it provides a more clear interpretation of results (since a large value in this ratio can be due either to high spending or to low per head GDP). Nevertheless we have also estimated a model using the ratio and find results in line with the ones in the paper. We do not show these results here for space reasons but are available upon request.
} 
education expenditure to the level of living of the country. If we did not do this, the impact of expenditure on education might be biased. Rich countries raise more revenue from taxes and can dedicate more resources to education. At the same time, they have lower poverty rates. Then, the impact of public expenditure in education would be overestimated. In particular, we add a variable called $G D P_{c t}$ that represents the logarithm of average per capita GDP when the individual was of age 15 to 17 . Not surprisingly, the two variables $P E$ and GDP are strongly correlated. ${ }^{16}$

Fourth, we also include a measure of "initial inequality" (denoted by $I N E Q_{c t}$ ). The idea is that countries with larger amounts of public expenditure may have unobserved characteristics (for instance, inequality levels) that correlate with both those levels of spending and current individual poverty status. If these inequality levels are positively correlated with current individual poverty, then our results would be overestimating the true impact of public spending (as measured here). For example, more unequal countries may spend more on other long term inequality-reduction policies (not captured in the measured proposed in the paper) which reduces individuals' probability of being poor when adults. However, these inequality levels might also be negatively correlated with individuals' current poverty status. For example, if some forms of expenditure are entitlements, those countries that are initially more unequal might need to spend more than countries with fewer poor families. In that case, our results would be underestimating the true impact of public spending on poverty reduction. Thus, it is very difficult to establish a priory the sign and magnitude of the bias if we do not account for this effect. ${ }^{17}$ Similarly to the case of $G D P$, we assign to each individual the average value of the Gini indexes in her country at the time she benefitted from each particular measure of $P E$. Note that both $G D P_{c t}$ and $I N E Q_{c t}$ take a different value for every combination of year of birth and country. They reflect initial circumstances that may have a long-run effect later in life. ${ }^{18}$

The crucial issue for identification is the assumption regarding exogeneity of public expenditure. Variation in this measure arises because of differences in expenditure across countries at the same point in time and differences in country expenditure over time. Either difference could be partly endogenous with respect to the poverty rate and related to both country

\footnotetext{
${ }^{16}$ The correlation coefficient is 0.66 when we consider our first measure of expenditure per capita, the one that adds expenditure at the three levels.

${ }^{17}$ There is some evidence in the related literature on that. For example, Sylwester (2000), in a crosscountry analysis finds that higher levels of initial income inequality are associated with higher public education expenditure. See also, Corak (2006) or Marx et al (2014) for additional discussion on the relationship between inequality and social policies.

${ }^{18}$ In the online Appendix, Section F, we check whether public expenditure has a similar impact on poverty reduction regardless of some contextual variables as country GDP or inequality. Results are very similar to the ones found for the main specification.
} 
expenditure and children's eventual income. The inclusion of GDP and $I N E Q$ as regressors helps to partially correct this endogeneity problem. However, there are many other factors that may have changed within particular countries between the time the individual was a teenager and the time of the survey. The inclusion of a time trend can capture a common trend, but cannot capture differences across countries over time. To address this problem we include two additional regressors that help to control for country-specific trends. These are the change in per capita GDP and the change in our measure of inequality from the time the individual was 15-17 until the year of survey response, respectively. Since we have two cross sections, these two regressors take different values for each combination of year of birth, country, and cross section. They control for possible changes that are happening within countries between the moment when expenditure was made and the moment when poverty status is determined. ${ }^{19}$

Another concern is that the place in which people end up living may also play a role in determining poverty status (at least in the US there is wide variation in rates intergenerational mobility across regions within counties, see Chetty et al., 2014) and therefore we include some region-cohort-specific controls. In particular, we include as controls both the unemployment level in the region of residence when the individual was 15-17, together with the change in the unemployment level between that time and the year of survey response. We decided not to do so in our main specification because there are many missing data in the unemployment variable. In fact, sample size reduces by almost one half. In Section 4, we comment on this.

Finally, since we combine individual-level data with group-level data in our explanatory variable of interest $\left(P E_{c t}\right)$, errors are clustered at the country and year of birth level. Since our dependent variable is a binary variable, we also estimate a probit model and obtain similar results. Thus, for the sake of brevity, we only report results from the OLS specification in the main text. ${ }^{20}$

Note that, according to the specification in Equation (1), if public expenditure during teen years reduces the probability of being poor as an adult, the estimated coefficient of $\beta_{1}$ should be negative. Moreover, if that effect works mainly through those individuals who come from families with a low level of education, the estimated coefficient of $\beta_{3}$ should be positive.

\footnotetext{
${ }^{19}$ An additional way to account for unobserved factors consists of interacting the cohort trends with the initial GDP and Inequality to allow separate trends for countries that have initially low or high productivity and inequality. We considered this possibility and obtained very similar qualitative results. See online Appendix, Section C.

${ }^{20}$ We show the results of estimating Equation (1) with a Probit specification (see online Appendix, Section D).
} 


\section{Results}

We begin by estimating seven alternative models using the different measures of public expenditure per capita presented in Section 2. In Model 1, we use the sum of public expenditure at the three educational levels. In Model 2, we only add expenditure in primary and secondary education. Models 3 to 5 consider only expenditure on primary, secondary, and tertiary education, respectively. In Model 6, we include expenditure on primary and secondary education, included separately. Finally, in Model 7 we include expenditure at the three levels, again separately. In the seven models, each spending category is interacted with the dummy variable $E D_{-} F A M_{i}$. All seven models include the full set of controls, with the exception of the rate of unemployment and its change. Later on, we include these additional controls to see if they affect our results. Since we want to concentrate on the effects of our main variables of interest, we present in Tables 3 and 4 the marginal effects corresponding to the different measures of government spending and to the dummy variable that describes the level of education in the family $\left(E D_{-} F A M_{i}\right){ }^{21}$ Table 3 calculates the overall effects of these variables, while in Table 4 we compute marginal effects of government expenditure, for each one of the two family types. ${ }^{22}$ Recall that the estimation we get for the parameter $\beta_{1}$ captures the effect of $P E$ on individuals from families with a low level of education, while the effect on those coming from families with a high education level is captured by the sum $\beta_{1}+\beta_{3}$. The overall marginal effect is simply a weighted sum of these two effects, where the weights correspond to the fraction of individuals in each group.

\section{Table 3}

The upper part of Table 3 shows a pattern that is consistent with the idea that higher public expenditure on primary and on secondary education is associated with lower poverty rates in adulthood. This association vanishes when we consider expenditure on tertiary education. The estimated marginal effects of total expenditure (Model 1), expenditure on compulsory education (Model 2), on primary education (Model 3), and on secondary education (Model 4) are all negative and significant at the $1 \%$ level except for total expenditure, which is significant only at the $5 \%$ level. The marginal effect of expenditure on tertiary education (Model 5) is not statistically different from zero. When we include separately expenditure at different levels (Models 6 and 7), we find that higher expenditure on primary and secondary

\footnotetext{
${ }^{21}$ Results remain unchanged after excluding observations with number of siblings above 19 and observations with youth unemployment rate above 75 (see Table 1). Results available upon request.

${ }^{22}$ In Section $\mathrm{E}$ of the online Appendix we present a table with the estimated coefficients corresponding to Models 1 to 7 .
} 
education is again associated with lower adult poverty rates. Interestingly, in Model 7 we find that more expenditure on tertiary education is associated with a higher incidence of adult poverty. A possible explanation could be that expenditure on primary and, in particular, secondary education helps to redistribute income. Notice that this is a type of expenditure that benefits most individuals, since attendance at these levels is compulsory in most countries. On the contrary, since attendance in tertiary education is not compulsory, expenditure at this level concentrates on the richest segment of the society. Another explanation could be that, since public expenditure is computed when individuals are in their teens, they are most likely to be affected by expenditure on secondary education since this is the level of education they are currently attending.

To illustrate the size of the effects we obtain, we focus on Model 4 in which we only consider expenditure on secondary education. The estimated marginal effect is -.0158 . This means that an increase of one standard deviation $(\$ 1,556)$ in expenditure is associated with a reduction of 0.61 percentage points in adult poverty. This is a sizable effect, since it represents a $5 \%$ of the mean value of the variable poor (the mean of poor is 0.1211 ). Nevertheless, this effect is dwarfed by the effect of having educated parents. In Model 4, we find that having educated parents is associated with a reduction of 6.75 percentage points in the probability of being poor, in line with what we saw in Table $2 .^{23}$

In the bottom part of Table 3, we add two additional regressors. These are the level of unemployment in the region of residence when the individual was 16, together with the change in the unemployment rate since that moment till of survey response. These unemployment rates are computed from the European Labor Force Survey. ${ }^{24}$ Data on unemployment rates are not available for all the country-cohorts we have in our sample. Because of this, using unemployment rates reduces our sample size from 140,053 to 84,121 observations in the case of Model 4. This means that the results are not directly comparable to those on the upper part of the table. In particular, we lose more than $50 \%$ of the observations from Austria, Finland, Hungary, Ireland, Norway, and Sweden. In terms of cohorts, we lose all observations from 1954 to 1957. In general, the inclusion of the unemployment rate means that we give more weight to younger cohorts. In any case, we find that the results are very much in line with those in the upper part of the table. In particular, the effect of expenditure on secondary education is even stronger than what we obtained in the upper part of the table.

\footnotetext{
${ }^{23}$ Results are also similar if we use alternative definitions of parental education. In Section A of the online Appendix we examine results by including instead separately two variables capturing both father and mother educational levels and also by defining three category dummies to capture three levels of educated parents instead of just two. We find very similar results.

${ }^{24}$ See the Eurostat website for an overview of the LFS:

http://ec.europa.eu/eurostat/web/microdata/european-union-labour-force-survey
} 
We also find that now expenditure on primary education does not seem to be associated with a reduction in poverty rates.

\section{Table 4}

Since the models we estimate contain an interaction term between expenditure and family type, this allows us to compute marginal effects separately according to family type. This is what Table 4 shows, for the baseline model that does not include unemployment rates. In the upper part of the table, we present the results corresponding to Models 1-5. Below, we present the results corresponding to models 6 and 7 . The general pattern is that the effect that public expenditure has on reducing adult poverty concentrates mostly on individuals from families with low education. In models 1-6, we find that the effect of expenditure is associated with a reduction in poverty rates only for individuals with parents with low education. For instance, an increase in expenditure on secondary education of the size of one standard deviation is associated with a reduction of between 1.18 and 1.25 percentage points in the incidence of poverty in adulthood for children from low-educated families depending on the particular model considered.

It is very interesting what happens in Model 5. The marginal effect for individuals from non-educated families is negative and highly significant (-0.0142), while the one corresponding to individuals from educated families is positive and also highly significant $(+0.0344)$. These two effects do not have similar sizes but do have opposite signs. This is the reason why in Table 3 we found no effect of public expenditure on poverty reduction, since the overall marginal effect we obtained $(+0.0034)$ is just the weighted average of the two marginal effects in Table $4 .^{25}$ In Model 7, we get mixed results. Similar to Models 4 and 6, expenditure in secondary education has a stronger association with poverty reduction for individuals from low educated families than for individuals from educated families. Expenditure in primary education seems to have a stronger effect on individuals from educated families, in opposition to results in Models 3 and 6.

Finally, expenditure on tertiary education in Model 7 follows a similar pattern to what happens in Model 5. Once we disaggregate by family type, its correlation with poverty status is negative for individuals from non-educated families and positive for the other group. Focusing again on Model 4, an increase of one standard deviation in expenditure in secondary education is associated with a reduction of 1.24 percentage points in adult poverty for individuals from families with low education.

\footnotetext{
${ }^{25}$ The weights are the proportion of individuals from educated and non-educated families, in particular 0.3636 and 0.6364 , for the observations used in the estimation of Model 5 .
} 
The general conclusion from Tables 3 and 4 is that higher public expenditure seems to be associated with lower adult poverty rates, although the effect seems to work through expenditure in primary and, in particular, secondary education. This finding is in line with previous results in the literature (see Mayer, 2002 or Mayer and Lopoo, 2008). ${ }^{26}$

Next we estimate again all Models 1-7, but using expenditure when individuals were of ages 10 to 12 . We do this to study whether the strong effect of expenditure on secondary education found in Tables 3 and 4 is due to the fact that most individuals aged 15-17 must be enrolled in secondary education. If that is the main reason, when using expenditure at ages 10-12 we should find a stronger effect of expenditure in primary education, since that is the level in which most individuals should be enrolled at that age. As we said above, results are not exactly comparable for two reasons. First, with this new measure of expenditure, we have fewer observations since now we lose all individuals born before 1959, while with our previous measures we had cohorts going back to 1954. In the case of Model 4, sample size drops from 140,053 to 110,152 . Second, the sample we use with this new measure is much younger since we are excluding the five older cohorts. As Table 5 shows, expenditure on secondary education is still the one that has the strongest association with poverty reduction. Expenditure at the other levels does not display any correlation with poverty reduction. ${ }^{27}$

\section{Table 5}

As a further illustration, we have used our results from Model 1 to compute predicted probabilities of being below the poverty line as a function of public expenditure for the two types of families. In particular, here we use our first measure of public expenditure, the one that combines expenditure at the three educational levels when individuals were of age 15-17 (Model 1). Figure 3 contains a plot of these probabilities. As can be seen in the figure, public expenditure seems to reduce the gap between the two types of families. However, even at the 99th percentile of total expenditure, there is still a gap between the probabilities for the

\footnotetext{
${ }^{26}$ As a robustness check, we regress poverty rates in adulthood on public expenditure from a different period than the one we are considering in our main specification. In particular, to each cohort from a given country, we randomly assign public expenditure corresponding to a different cohort from the same country. We find that the effect of public expenditure is not significant in most cases. Therefore, the actual measures of public expenditure are meaningful determinants of the variation of current poverty rates among individuals. See online Appendix, Section F.

${ }^{27}$ Similar results are obtained while estimating Models 1-7 using expenditure at age 10-12 and age 15-17 on the same smaller set of observations. These results are not shown for conciseness but available from the authors upon request.
} 
two groups. ${ }^{28}$

Figure 3

We see that the effect of public expenditure on poverty is negative among individuals from low educated families and positive among individuals with high educated parents. Therefore we can conclude that the negative relationship between public expenditure and poverty observed at the country level for individuals with parents with low education (see Figure 2 above) still holds at the individual level.

Before closing this section, we want to comment briefly on the possible mechanisms behind the effect of public expenditure in adult poverty. There is a recent literature that points to the existence of a positive link between public expenditure on education and academic achievements. One possibility is that when we invest more resources in education, some individuals benefit because they acquire more education. In particular, they may decide not to drop out of school after finishing compulsory education. This, in turn, may reduce the probability of being below the poverty line when adults. Some recent studies provide evidence on the potential mechanisms from which these spending effects arise. For instance, Bhalotra et al. (2015) find that the removal of primary schools fees in developing countries is associated with roughly 0.2 more years of schooling. They also find that this effect is stronger for children of women with less schooling. Bellani and Bia (2016) use data from the 2005 and 2011 EU-SILC and find that exposure to poverty in childhood reduces the probability of completing at least secondary education by 12 percentage points. Finally, Jackson et al. (2016) find that spending increases are associated with sizable improvements in measured school inputs, including reductions in student teacher ratios, increases in teacher salaries, and longer school years, which in turn improve individuals' adult outcomes.

\section{Concluding remarks}

Being raised in a poor household may have negative long-run effects on individual welfare. Here we study whether and to what extent these long-run effects of poverty are mitigated by public expenditure.

Our main finding is that public expenditure has a strong long-run effect on reducing the incidence of poverty in adulthood. In addition, we find that this effect concentrates mostly on individuals who were raised in families with a low level of education. This result suggests

\footnotetext{
${ }^{28}$ Predicted probabilities of poor at the 99 percentile of public expenditure are .085 for individuals from educated families and .113 for the other group. We reject the hypothesis that these two probabilities are equal ( $p$-value is 0.0001$)$.
} 
that public expenditure increases intergenerational income mobility.

We believe that our results could be relevant for several recent debates in the literature on the economics of education. In particular, they lend support to policies that promote increasing expenditure on basic education, for example, by reducing the compulsory school entry age, or by improving the quality of the education provided at early stages.

This study have several limitations. The most important one is the lack of a source of plausibly exogenous variation in public expenditure, implying that the estimated coefficients may reflect the effects of other unobserved factors correlated both with expenditure and with adult poverty status. The inclusion of several controls that capture country-specific time trends may help to mitigate this concern. Another relatively minor concern is that we do not have a direct measure of government investment in education and thus we follow previous research in using government spending as a proxy for government investment (see Mayer and Lopoo, 2008). However, public expenditure could be an imperfect measure of actual investment. For example, countries that spend similar amounts might be spending it differently and having different results with the same level of expenditure depending on several other circumstances. Moreover, we lack data on private expenditure on education, although some of the variables describing household characteristics can be seen as proxies of such expenditure. 


\section{References}

Akin, J.S., Garfinkel, I.: The Quality of Education and Cohort Variation in Black-White Earnings Differentials: Comment. American Economic Review 70, 1, 186-191 (1980).

Atkinson A.: Macerata Lectures on European Economic Policy. Poverty and the EU: the New Decade. Working Paper 24-2010, Macerata University, Department of Studies on Economic Development (DiSSE) (2010).

Atkinson A., Piketty T., Saez, E.: Top Incomes in the Long Run of History. Journal of Economic Literature 49, 1, 3-71 (2011).

Bellani, L., Bia, M. : Intergenerational poverty transmission in Europe: The role of education. Working Paper Series 2016-02, University of Konstanz (2016).

Bhalotra, S., Harttgen, K., Klasen, S.: The impact of school fees on schooling outcomes and the intergenerational transmission of education, University of Bristol (2015).

Blanden, J., Gregg, P.: Family income and educational attainment: a review of approaches and evidence for Britain. Oxford Review of Economic Policy 20 (2), 245-263 (2004).

Chetty, R., Hendren, N., Kline P., Saez, E.: Where is the Land of Opportunity? The Geography of Intergenerational Mobility in the United States. Quarterly Journal of Economics 129 (4), 1553-1623 (2014).

Corak, M.: Do poor children become poor adults? Lessons for public policy from a cross country comparison of generational earnings mobility. Research on Economic Inequality 13, 143-188 (2006).

Corcoran, M., Adams, T.: Race, sex and the intergenerational transmission of poverty. In: Duncan, G. J. and Brooks-Gunn, J. (eds.) Consequences of growing up poor, pp. 461-517. Russell Sage Foundation, New York (1997).

Figari, F.: Cross-national differences in determinants of multiple deprivation in Europe. Journal of Economic Inequality 10, 397-418 (2012).

Grogger, J.: School expenditures and post-schooling earnings: evidence from the high school and beyond. Review of Economics and Statistics 78, 4, 628-637 (1996). 
Hanushek, E.: School resources and student performance. In: Burtless, G. (ed.), Does Money Matter? The Effect of School Resources on Student Achievement and Adult Success. Brookings Institution Press, Washington, D.C. (1996).

Hanushek, E.: Spending on schools. In: Moe, T. (ed.), A Primer on American Education, pp. 69-88. Hoover Institution Press, Palo Alto, CA (2001).

Hedges, L.V., Laine, R., Greenwald, R.: Does money matter? Meta-analysis of studies of the effects of differential school inputs on student outcomes. Educational Researcher 23, 3, 5-14 (1992).

Hertz, T., Jayasunderay, T., Pirainoz, P., Selcuk, S., Smithyy, N., Verashchagina, A.: The Inheritance of Educational Inequality: International Comparisons and Fifty-Year Trends. The B.E. Journal of Economic Analysis and Policy 7, Article 10 (2007).

Hidalgo-Hidalgo, M, Iturbe-Ormaetxe, I.: Long-run effects on poverty of public expenditure in education. IVIE-Working Papers AD 2014-06 (2014).

Holmlund, H., Lindahl, M., Plug, E.: The causal effect of parents' schooling on children's schooling: A comparison of estimation methods. Journal of Economic Literature 49 (3), 615-651 (2011).

Jackson, C.K., Johnson, R., Persico, C.: The Effects of School Spending on Educational and Economic Outcomes: Evidence from School Finance Reforms. The Quarterly Journal of Economics, 131 (1), 157-218 (2016).

Jäntti, M., Jenkins, S.: Income mobility. In Atkinson, A., Bourguignon, F. (eds.) Handbook of Income Distribution, Volume 2B, pp. 807-936, Elsevier (2014).

Jenkins, S., Siedler, T.: The intergenerational transmission of poverty in industrialized countries. Chronic Poverty Research Centre Working Paper 75, Institute for Social and Economic Research, University of Essex (2007).

Jenkins, S., Brandolini, A., Micklewright, J., Nolan, B. (eds): The Great Recession and the Distribution of Household Income. Oxford University Press (2013).

Marx, I., Nolan, B., Olivera, J.: The welfare state and anti-poverty policy in rich countries. In Atkinson, A., Bourguignon, F. (eds.) Handbook of Income Distribution, Volume 2B, pp. 2063-2140, Elsevier (2014). 
Mayer, S. E.: The Influence of Parental Income on Children's Outcomes: A Review. Report to the New Zealand Ministry of Social Development (2002).

Mayer, S. E., Lopoo, L. M.: Government spending and intergenerational mobility. Journal of Public Economics 92, 139-158 (2008).

Meghir, C., Palme, M.: Educational Reform, Ability, and Family Background. American Economic Review 95, 1, 414-424 (2005).

Morelli, S., Smeeding, T., Thompson, J.: Post-1970 trends in within-country inequality and poverty: Rich and middle income countries. In Atkinson, A., Bourguignon, F. (eds.) Handbook of Income Distribution, Volume 2A, pp. 596-693, Elsevier, (2015).

Nolan, B. and Marx, I.: Inequality, poverty and social exclusion. In Salverda, W., Nolan, B., Smeeding, T. (eds) Oxford Handbook of Economic Inequality, Oxford: Oxford University Press (2009).

OECD: An Overview of Growing Income Inequalities in OECD Countries: Main Findings. OECD Publishing, Paris (2011).

OECD: Crisis squeezes income and puts pressure on inequality and poverty. OECD Publishing, Paris (2013).

Piketty, T.: Capital in the Twenty-First Century, Harvard University Press (2014).

Piopiunik, M.: Intergenerational transmission of education and mediating channels: Evidence from a compulsory schooling reform in Germany. The Scandinavian Journal of Economics 116 (3), 878-907 (2014).

Sylwester, K.: Income inequality, education expenditures and growth. Journal of Development Economics 63, 379-398 (2000).

Wolff, P., Montaigne, F., Rojas González, G.: Investing in statistics: EU-SILC. In Atkinson, A., Marlier, E. (eds) Income and Living Conditions in Europe, Chapter 2, pp. 38-55. Luxembourg: Eurostat (2010). 


\section{Appendix: Variable Description}

- Expenditure per student, primary, secondary and tertiary: Public expenditure per student is the public current spending on education divided by the total number of students at that level. Public expenditure (current and capital) includes government spending on educational institutions (both public and private), education administration as well as subsidies for private entities (students/households and other privates entities). Data are in constant 2000 U.S. dollars, and are corrected by PPP. Sources: United Nations Educational, Scientific, and Cultural Organization (UNESCO) Institute for Statistics and PPP data are from the World Bank.

- GDP per capita: It is gross domestic product divided by midyear population. GDP is the sum of gross value added by all resident producers in the economy plus any product taxes and minus any subsidies not included in the value of the products. It is calculated without making deductions for depreciation of fabricated assets or for depletion and degradation of natural resources. Data are in constant 2000 U.S. dollars and are corrected by PPP. Source: World Bank national accounts data, and OECD National Accounts data files.

- Educated family: A dummy variable that takes value 1 if either the education the father or mother had attained when the individual was around 14 years old is at least upper secondary education. Source: EU-SILC

- Father unemployed: A dummy variable that takes value 1 if the father was unemployed when the individual was 14 years old. Source: EU-SILC.

- Siblings: It is the number of siblings the individual's had when he/she was around 14 years old. Source: EU-SILC.

- Citizenship: It generally corresponds to the country issuing the passport. It refers to current (at the time of survey) national boundaries. It is a dummy variable that takes value 1 if citizenship corresponds to the country of residence. Source: EU-SILC

- Inequality: It is the country average inequality during the previous years (3-5) to the period of individual's primary school attendance. Source: Estimated Household Income Inequality Data Set (EHII), which is a panel of estimated Gini coefficients. The EHII is a global dataset on inequality derived by the University of Texas Inequality Project (UTIP) 
- Unemployment rate: It is the regional (at the level of NUTS-2) youth unemployment rate in the region of residence when the individual was 15-17. Source: EU Labor Force Survey, Eurostat and US Bureau of Labor Statistics, International Comparisons.

- Single mother: It is a dummy variable that takes value 1 if the individual lived with only his mother when he/she was around 14 years old. Source: EU-SILC.

- CS2011: It is a dummy variable that takes value 1 if the observation belongs to the 2011 cross section. Source: EU-SILC. 
Table 1: Summary Statistics

\begin{tabular}{|c|c|c|c|c|c|}
\hline Variable & Mean & Std.Dev. & Min & Max & Obs \\
\hline Poor & 0.121 & 0.326 & 0 & 1 & 163,133 \\
\hline Female & 0.508 & 0.500 & 0 & 1 & 163,159 \\
\hline Non citizen & 0.00349 & 0.0590 & 0 & 1 & 162,915 \\
\hline Year 2011 & 0.521 & 0.500 & 0 & 1 & 163,159 \\
\hline Educated family & 0.355 & 0.478 & 0 & 1 & 153,517 \\
\hline Single mother family & 0.0765 & 0.266 & 0 & 1 & 157,600 \\
\hline Nu mber of sib lings & 1.791 & 1.687 & 0 & 40 & 155,908 \\
\hline Father unemployed & 0.00918 & 0.0954 & 0 & 1 & 147,536 \\
\hline Per pupil exp. education (age 15-17), year 2000 US dollars (PPP) & $13,034.6$ & $6,336.4$ & $3,905.5$ & $39,648.3$ & 163,159 \\
\hline Per pupil exp. compulsory education (age 15-17), year 2000 US dollars (PPP) & $6,039.3$ & $2,613.2$ & $1,246.6$ & $17,710.6$ & 163,159 \\
\hline Per pupil exp. primary education (age 15-17), year 2000 US dollars (PPP) & $2,742.0$ & $1,422.1$ & 441.5 & $9,034.6$ & 163,159 \\
\hline Per pupil exp. secondary education (age 15-17), year 2000 US dollars (PPP) & $3,297.3$ & $1,555.8$ & 604.9 & $10,517.8$ & 163,159 \\
\hline Per pupil exp. tertiary education (age 15-17), year 2000 US dollars (PPP) & $6,995.3$ & 4,492.6 & $1,857.4$ & $31,475.1$ & 163,159 \\
\hline Per capita GDP (age 15-17), year 2000 US dollars (PPP) & $16,324.5$ & 3,971.4 & $5,742.1$ & $35,686.7$ & 163,159 \\
\hline Income Inequality (age 15-17) & 35.94 & 3.428 & 27.59 & 43,49 & 158,489 \\
\hline Youth unemp loyment rate (age 16-21) & 32.82 & 19.27 & 0 & 92,03 & 102,476 \\
\hline \multicolumn{6}{|l|}{ Country dummies } \\
\hline AT & & & & & 8,828 \\
\hline $\mathrm{BE}$ & & & & & 7,051 \\
\hline DK & & & & & 3,387 \\
\hline ES & & & & & 23,637 \\
\hline FI & & & & & 8,106 \\
\hline FR & & & & & 15,862 \\
\hline GR & & & & & 9,581 \\
\hline $\mathrm{HU}$ & & & & & 4,781 \\
\hline IE & & & & & 7,008 \\
\hline IT & & & & & 32,769 \\
\hline LU & & & & & 3,265 \\
\hline NL & & & & & 9,083 \\
\hline NO & & & & & 4,363 \\
\hline PT & & & & & 7,820 \\
\hline SE & & & & & 4,660 \\
\hline \multirow[t]{2}{*}{ UK } & & & & & 12,958 \\
\hline & & & & & 163,159 \\
\hline
\end{tabular}

Note: Sample: Individuals for which the variable Per pupil expenditure in education is not missing. Source: EU-SILC 2005 and 2011 and UNESCO Database. 


\begin{tabular}{|c|c|c|c|c|c|c|c|}
\hline I. Baseline & Model 1 & Model 2 & Model 3 & Model 4 & Model 5 & Model 6 & Model 7 \\
\hline Total exp. & $\begin{array}{c}-0.0128^{* *} \\
(0.0065)\end{array}$ & & & & & & \\
\hline Exp. in compulsory educ & & $\begin{array}{c}-0.0322 * * * \\
(0.0073)\end{array}$ & & & & & \\
\hline Exp. in primary educ & & & $\begin{array}{c}-0.0139 * * * \\
(0.0053)\end{array}$ & & & $\begin{array}{c}-0.0126^{* *} \\
(0.0054)\end{array}$ & $\begin{array}{c}-0.0157 * * * \\
(0.0057)\end{array}$ \\
\hline Exp. in secondary educ & & & & $\begin{array}{c}-0.0158 * * * \\
(0.0041)\end{array}$ & & $\begin{array}{c}-0.0159 * * * \\
(0.0040)\end{array}$ & $\begin{array}{c}-0.0204 * * * \\
(0.0042)\end{array}$ \\
\hline Exp. in tertiary educ & & & & & $\begin{array}{c}0.0034 \\
(0.0046)\end{array}$ & & $\begin{array}{c}0.0096^{* *} \\
(0.0048)\end{array}$ \\
\hline Family educated & $\begin{array}{c}-0.0688 * * * \\
(0.0028)\end{array}$ & $\begin{array}{c}-0.0684 * * * \\
(0.0028)\end{array}$ & $\begin{array}{c}-0.0657 * * * \\
(0.0029)\end{array}$ & $\begin{array}{c}-0.0688 * * * \\
(0.0028)\end{array}$ & $\begin{array}{c}-0.0675^{* * * *} \\
(0.0027)\end{array}$ & $\begin{array}{c}-0.0687 * * * \\
(0.0028)\end{array}$ & $\begin{array}{c}-0.0694 * * * \\
(0.0027)\end{array}$ \\
\hline Observations & 138,512 & 139,807 & 141,701 & 140,053 & 144,349 & 139,807 & 138,512 \\
\hline
\end{tabular}

II. Adding une mployment and its change

$\begin{array}{ll}\text { Total exp. } & -0.0185 \\ & (0.0114)\end{array}$

Exp. in compulsory educ

$$
\begin{gathered}
-0.0399 * * * \\
(0.0091)
\end{gathered}
$$

Exp. in primary educ

$$
\begin{aligned}
& -0.0126 \\
& (0.0102)
\end{aligned}
$$$$
-0.0062 \quad-0.0156
$$$$
\text { (0.0083) }
$$$$
\text { (0.0094) }
$$

Exp. in secondary

$$
\begin{gathered}
-0.0250 * * * \\
(0.0049)
\end{gathered}
$$$$
-0.0238 * * *
$$$$
-0.0288 * * *
$$

Exp. in tertiary educ

$$
\text { (0.0047) }
$$

$$
0.0039
$$$$
0.0197 * *
$$

Family educ ated

$$
\begin{array}{ccccccc} 
& & & & (0.0103) & & 0.0090) \\
-0.0732 * * * & -0.0729 * * * & -0.0711 * * * & -0.0739 * * * & -0.0724 * * * & -0.0740 * * * & -0.0745 * * * \\
(0.0032) & (0.0031) & (0.0033) & (0.0031) & (0.0032) & (0.0031) & (0.0031)
\end{array}
$$

Observations 82,580

83,875

83,875

84,121

82,826

83,875

82,580

Notes: $* * * \mathrm{p}<0.01, * * \mathrm{p}<0.05, * \mathrm{p}<0.1$. Standard errors are clustered at the country-year of birth level. Source: EU-SILC 2005 and 201, UNESCO Database and EU Labor Force Survey, Eurostat (see the Appendix for the variables definition). 
Table 4: Decomposition of the marginal effect of public expenditure (15-17 years old)

\begin{tabular}{|c|c|c|c|c|c|}
\hline I. Baseline Models 1-5 & Total & Compulsory & Primary & Secondary & Tertiary \\
\hline Educated family $=0$ & $\begin{array}{c}-0.0347 * * * \\
(0.0066)\end{array}$ & $\begin{array}{c}-0.0510 * * * \\
(0.0076)\end{array}$ & $\begin{array}{c}-0.0281 * * * \\
(0.0059)\end{array}$ & $\begin{array}{c}-0.0322 * * * \\
(0.0041)\end{array}$ & $\begin{array}{c}-0.0142 * * * \\
(0.0048)\end{array}$ \\
\hline Educated family $=1$ & $\begin{array}{c}0.0255 * * * \\
(0.0073)\end{array}$ & $\begin{array}{c}0.0002 \\
(0.0081)\end{array}$ & $\begin{array}{l}0.0103 * \\
(0.0059)\end{array}$ & $\begin{array}{c}0.0126 * * \\
(0.0055)\end{array}$ & $\begin{array}{c}0.0344 * * * \\
(0.0053)\end{array}$ \\
\hline Observations & 138,512 & 139,807 & 141,701 & 140,053 & 144,349 \\
\hline
\end{tabular}

\section{B aseline Model 6}

$\begin{array}{lcc}\text { Educated family }=\mathbf{0} & -0.0135^{* *} & -0.0316^{* * *} \\ & (0.0066) & (0.0045) \\ \text { Educated family }=\mathbf{1} & -0.0111^{*} & 0.0114^{*} \\ & (0.0065) & (0.0061)\end{array}$

Observations

$139,807 \quad 139,807$

III. B aseline Model 7

\begin{tabular}{lccc} 
Educated family = & $-0.0144 * *$ & $-0.0303 * * *$ & -0.0021 \\
& $(0.0069)$ & $(0.0047)$ & $(0.0050)$ \\
Educated family $=\mathbf{1}$ & $-0.0181 * * *$ & -0.0031 & $0.0300 * * *$ \\
& $(0.0069)$ & $(0.0077)$ & $(0.0065)$ \\
Observations & 138,512 & 138,512 & 138,512 \\
\hline \hline
\end{tabular}

Note: Sample: Individuals for which the variable Per pupil expenditure in education is not missing. Source: EU-SILC 2005 and 2011 and UNESCO Database. 
Table 5: Overall marginal effects of public expenditure (10-12 years old)

I. Baseline Model 1

Model 2

Model 3

Model 4

Model 5

Model 6

Model 7

Total exp.

$$
0.0050
$$

$(0.0074)$

Exp. in compulsory educ $-0.0085$

(0.0101)

Exp. in primary educ

$$
\begin{gathered}
0.0103 \\
(0.0072)
\end{gathered}
$$$$
0.0146^{* *} \quad 0.0115
$$

Exp. in secondary educ

$$
\begin{gathered}
-0.0232 * * * \\
(0.0057)
\end{gathered}
$$$$
-0.0232 * * * \quad-0.0266 * * *
$$$$
\text { (0.0055) (0.0058) }
$$

Exp. in tertiary educ

$$
\begin{array}{ccccccc} 
& & & & 0.0061 & & 0.0086 \\
-0.0710 * * * & -0.0711 * * * & -0.0679 * * * & -0.0717 * * * & -0.0694 * * * & -0.0717 * * * & -0.0720 * * * \\
(0.0028) & (0.0029) & (0.0030) & (0.0029) & (0.0027) & (0.0030) & (0.0029)
\end{array}
$$

Family educated

Observations 109,560 110,152 111,901 110,152 115,218 110,152 109,560

Notes: $* * * \mathrm{p}<0.01, * * \mathrm{p}<0.05, * \mathrm{p}<0.1$. Standard errors are clustered at the country-year of birth level. Source: EU-SILC 2005 and 2011 and UNESCO Database (see the Appendix for the variables definition). 
Figure 1: Poverty rate by country

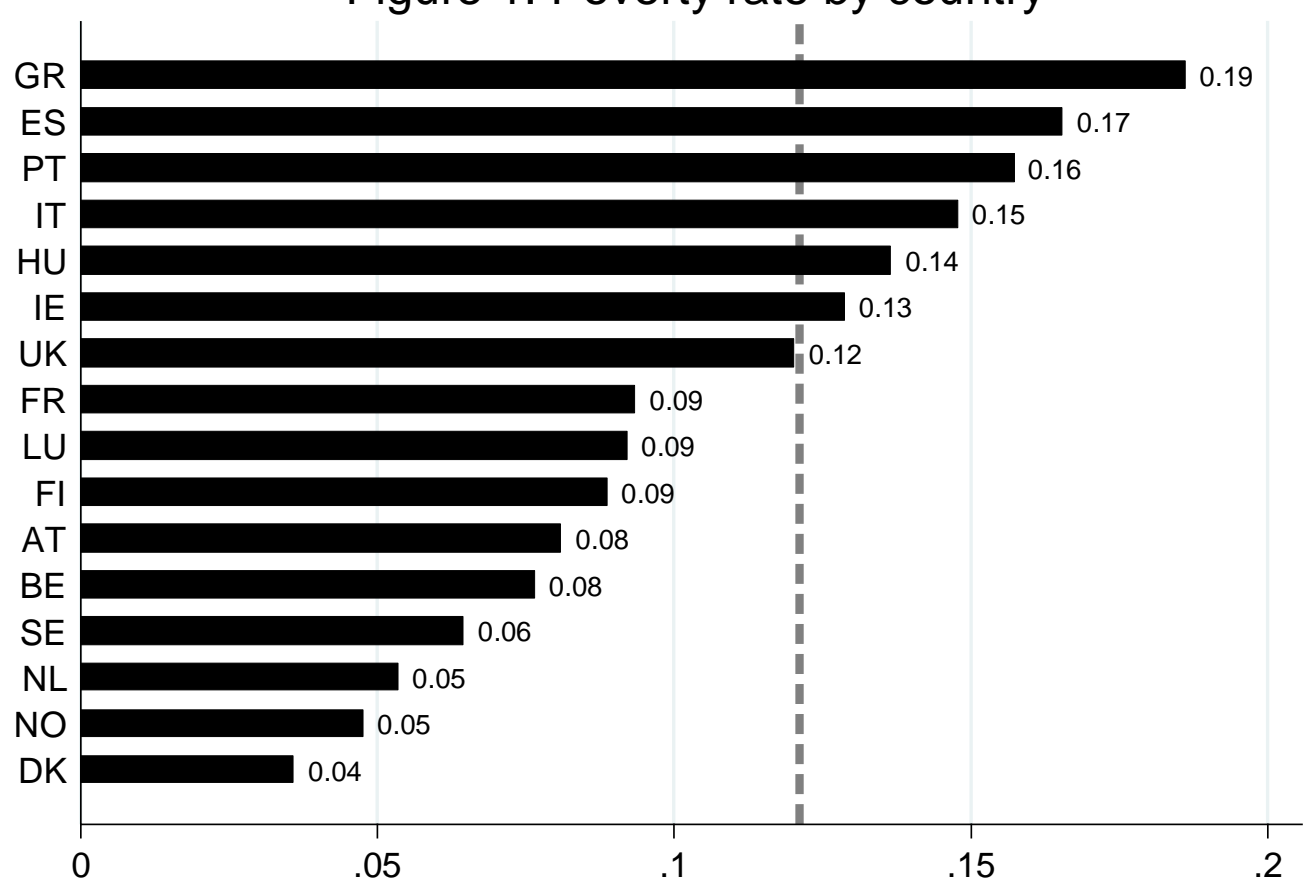

Notes: Only individuals between ages 25 and 57 . We exclude individuals not born in the corresponding country. Source: EU-SILC, waves 2005 and 2011.

Figure 2: Public expenditure and poverty rates

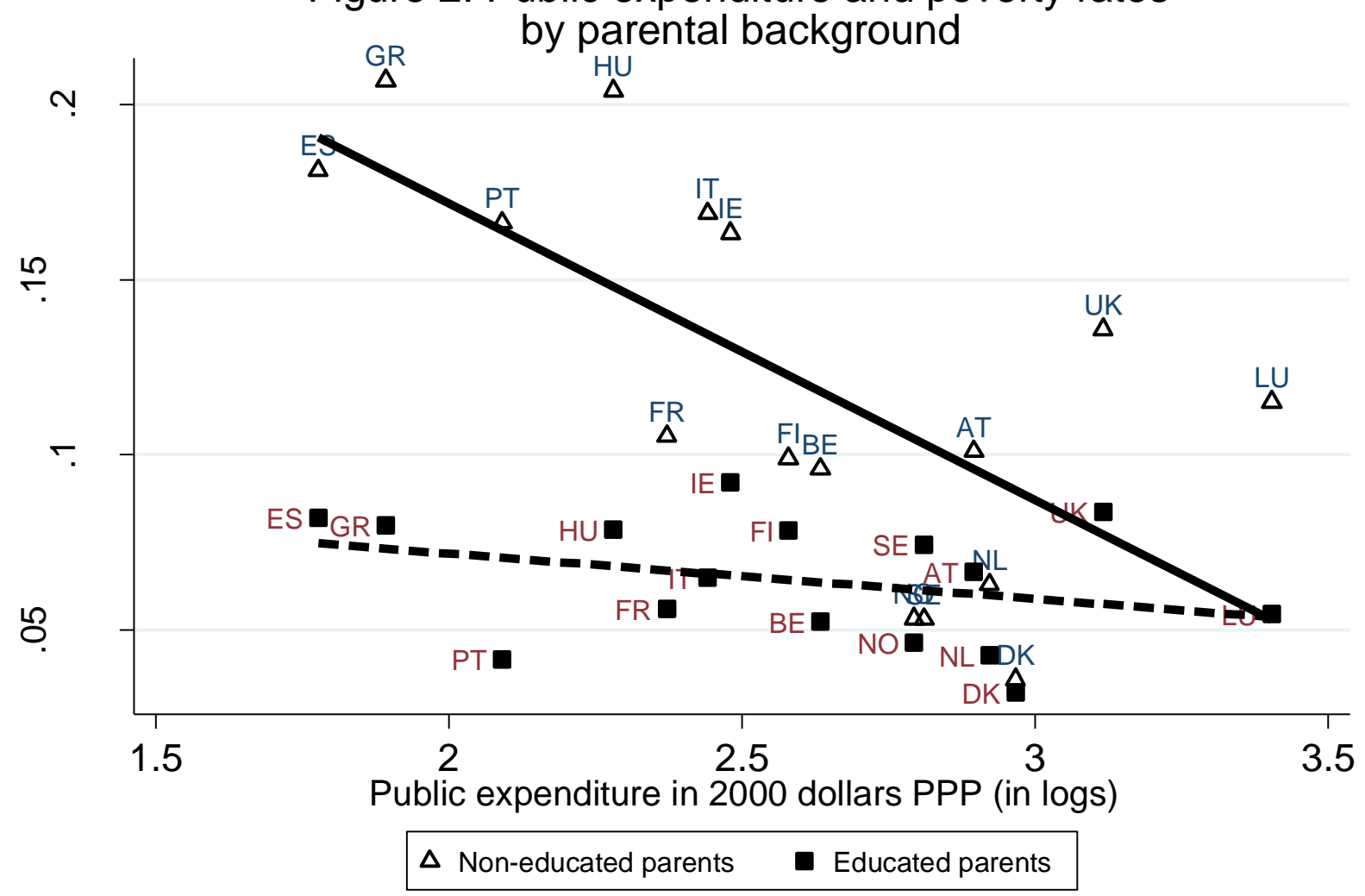


Figure 3: Predicted effect of PE on poverty by family background

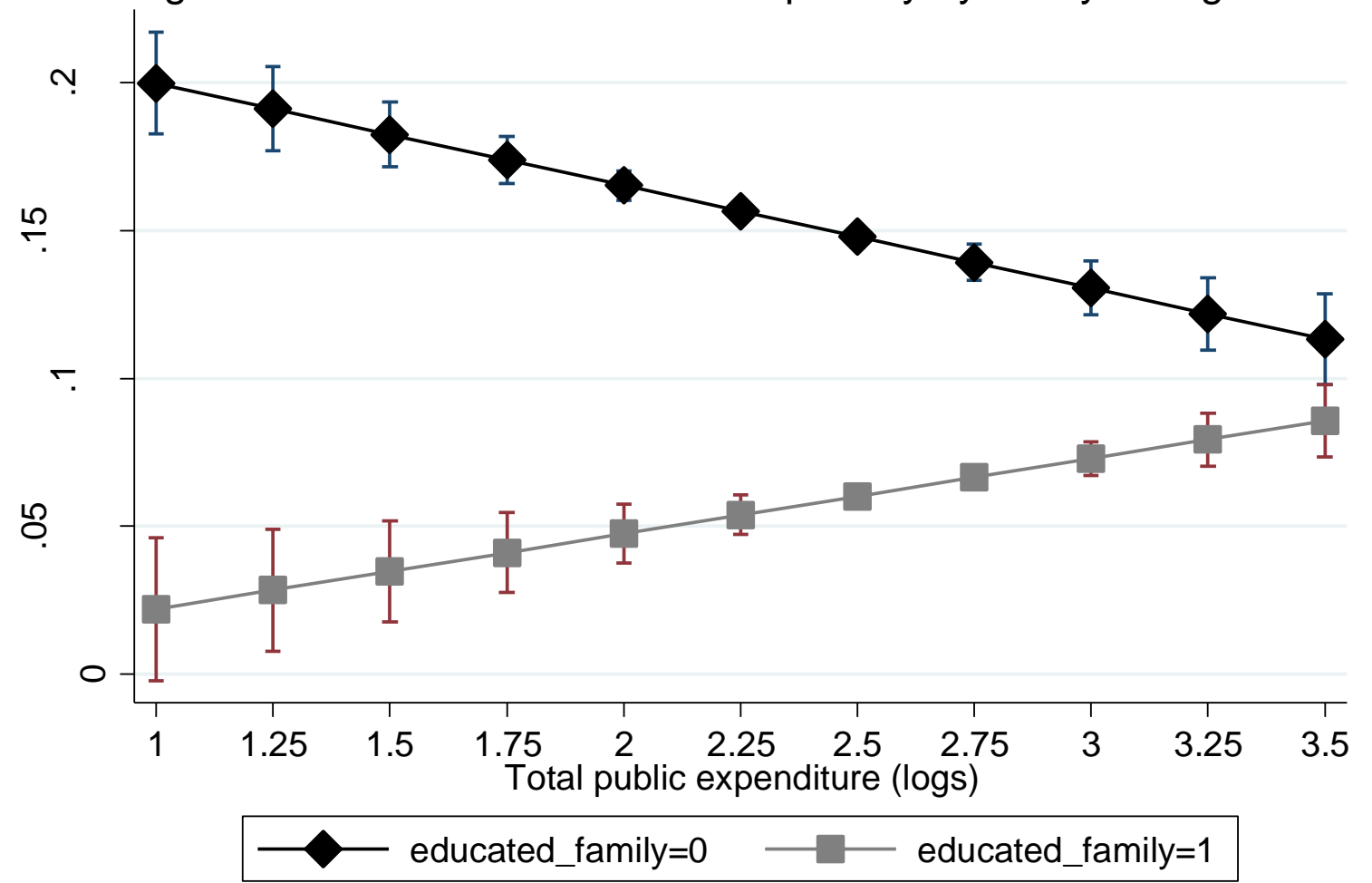




\title{
Online appendix to
}

\section{Long-run Effects of Public Expenditure on Poverty}

\author{
Marisa Hidalgo-Hidalgo and Iñigo Iturbe-Ormaetxe
}

\section{A. Parental education}

In this section we explore whether our results are sensitive to the definition of parental education. First we present the results of estimating the model in Equation (1) introducing separately the educational levels of both parents.

Table 1A: Overall marginal effects of public expenditure: father and mother education

\begin{tabular}{|c|c|c|c|c|c|c|c|}
\hline Variables & Model 1 & Model 2 & Model 3 & Model 4 & Model 5 & Model 6 & Model 7 \\
\hline Total exp. & $\begin{array}{c}-0.0154 * * \\
(0.0066)\end{array}$ & & & & & & \\
\hline Exp. in compulsory education & & $\begin{array}{c}-0.0332 * * * \\
(0.0075)\end{array}$ & & & & & \\
\hline Exp. in primary education & & & $\begin{array}{c}-0.0136 * * \\
(0.0055)\end{array}$ & & & $\begin{array}{c}-0.0118^{* *} \\
(0.0056)\end{array}$ & $\begin{array}{c}-0.0143^{* *} \\
(0.0059)\end{array}$ \\
\hline Exp. in secondary education & & & & $\begin{array}{c}-0.0170 * * * \\
(0.0042)\end{array}$ & & $\begin{array}{c}-0.0170 * * * \\
(0.0041)\end{array}$ & $\begin{array}{c}-0.0209 * * * \\
(0.0044)\end{array}$ \\
\hline Exp. in tertiary education & & & & & $\begin{array}{c}0.0016 \\
(0.0047)\end{array}$ & & $\begin{array}{c}0.0076 \\
(0.0051)\end{array}$ \\
\hline Father educated & $\begin{array}{c}-0.0501 * * * \\
(0.0025)\end{array}$ & $\begin{array}{c}-0.0496 * * * \\
(0.0025)\end{array}$ & $\begin{array}{c}-0.0484 * * * \\
(0.0026)\end{array}$ & $\begin{array}{c}*-0.0490 * * * \\
(0.0025)\end{array}$ & $\begin{array}{c}-0.0497 * * * \\
(0.0024)\end{array}$ & $\begin{array}{c}-0.0495 * * * \\
(0.0025)\end{array}$ & $\begin{array}{c}-0.0504 * * * \\
(0.0024)\end{array}$ \\
\hline Mother educated & $\begin{array}{c}-0.0380 * * * \\
(0.0027)\end{array}$ & $\begin{array}{c}-0.0378^{* * *} * \\
(0.0028)\end{array}$ & $\begin{array}{c}-0.0351 * * * \\
(0.0027)\end{array}$ & $\begin{array}{c}-0.0384 * * * \\
(0.0026)\end{array}$ & $\begin{array}{c}-0.0361 * * * \\
(0.0026)\end{array}$ & $\begin{array}{c}-0.0379 * * * \\
(0.0027)\end{array}$ & $\begin{array}{c}-0.0384 * * * \\
(0.0027)\end{array}$ \\
\hline Observations & 131,167 & 132,423 & 134,083 & 132,654 & 136,717 & 132,423 & 131,167 \\
\hline
\end{tabular}

Notes: $* * * \mathrm{p}<0.01, * * \mathrm{p}<0.05, * \mathrm{p}<0.1$. Standard errors are clustered at the country -year of birth level.

As can be observed, the effect of father's education on poverty reduction is somewhat larger than that of mother's education. The results regarding the impact of public expenditure are very similar to the ones shown in Table 3, although the sample size gets lower because of the large increase in missing values. Observe that our dummy variable "educated_family" categorizes as non-educated family those with 1 "non-missing" parent without secondary education and 1 "missing" parent with secondary education. Note that this definition might increase measurement error. However, it does not threaten the main findings. Observe that this measurement error would likely introduce a positive bias on the negative impact of public expenditure on poverty: some individuals with educated family, for which public expenditure 
has no effect, are pooled with individuals from non-educated families. Thus, if we could separate them the effect of public expenditure would be larger.

Next we define parental education through three dummies that will be equal to 1 if either the mother or the father has primary, secondary or tertiary education, respectively. We estimated Equation (1) using this alternative definition. Table 2D shows the results for this definition of parental education (Models 1-7):

Table 2A: Ove rall marginal effects of public expenditure: educated family (three categories)

\begin{tabular}{|c|c|c|c|c|c|c|c|}
\hline Variables & Model 1 & Model 2 & Model 3 & Model 4 & Model 5 & Model 6 & Model 7 \\
\hline Total exp. & $\begin{array}{c}-0.0132 * * \\
(0.0065)\end{array}$ & & & & & & \\
\hline Exp. in compulsory e ducation & & $\begin{array}{c}-0.0329 * * * \\
(0.0073)\end{array}$ & & & & & \\
\hline Exp. in primary education & & & $\begin{array}{c}-0.0140 * * * \\
(0.0053)\end{array}$ & & & $\begin{array}{c}-0.0131^{* *} \\
(0.0054)\end{array}$ & $\begin{array}{c}-0.0161 * * * \\
(0.0058)\end{array}$ \\
\hline Exp. in secondary e ducation & & & & $\begin{array}{c}-0.0159 * * * \\
(0.0041)\end{array}$ & & $\begin{array}{c}-0.0161 * * * \\
(0.0040)\end{array}$ & $\begin{array}{c}-0.0207 * * * \\
(0.0043)\end{array}$ \\
\hline Exp. in tertiary education & & & & & $\begin{array}{c}0.0033 \\
(0.0046)\end{array}$ & & $\begin{array}{c}0.0097^{* *} \\
(0.0048)\end{array}$ \\
\hline Family educated (Sec Educ) & $\begin{array}{c}-0.0557 * * * \\
(0.0029)\end{array}$ & $\begin{array}{c}-0.0545^{* * * *} \\
(0.0029)\end{array}$ & $\begin{array}{c}-0.0519 * * * \\
(0.0029)\end{array}$ & $\begin{array}{c}-0.0550 * * * \\
(0.0029)\end{array}$ & $\begin{array}{c}-0.0545 * * * \\
(0.0028)\end{array}$ & $\begin{array}{c}-0.0547 * * * \\
(0.0029)\end{array}$ & $\begin{array}{c}-0.0558 * * * \\
(0.0029)\end{array}$ \\
\hline Family e ducated (Ter Educ) & $\begin{array}{c}-0.0549 * * * \\
(0.0025)\end{array}$ & $\begin{array}{c}-0.0555^{* * * *} \\
(0.0026)\end{array}$ & $\begin{array}{c}-0.0542 * * * \\
(0.0027)\end{array}$ & $\begin{array}{r}-0.0542 * * * \\
(0.0025)\end{array}$ & $\begin{array}{c}-0.0537 * * * \\
(0.0025)\end{array}$ & $\begin{aligned} &-0.0554 * * * * \\
&(0.0025)\end{aligned}$ & $\begin{array}{c}-0.0558^{* * * *} \\
(0.0025)\end{array}$ \\
\hline Observations & 138,512 & 139,807 & 141,701 & 140,053 & 144,349 & 139,807 & 138,512 \\
\hline
\end{tabular}

Notes: $* * * \mathrm{p}<0.01, * * \mathrm{p}<0.05, * \mathrm{p}<0.1$. Standard errors are clustered at the country-year of birth level.

Again, results are very similar to the ones in Table (3) in the paper. Thus, the impact of public expenditure on current poverty status does not depend on how parental education is defined. 


\section{B. Poverty and parental education}

In this Section we provide a brief description of the correlation between current poverty status and family background, as measured by parental education. We illustrate these correlations in Figure 1A below, where we represent poverty rates by country for individuals with educated and non-educated parents, respectively.

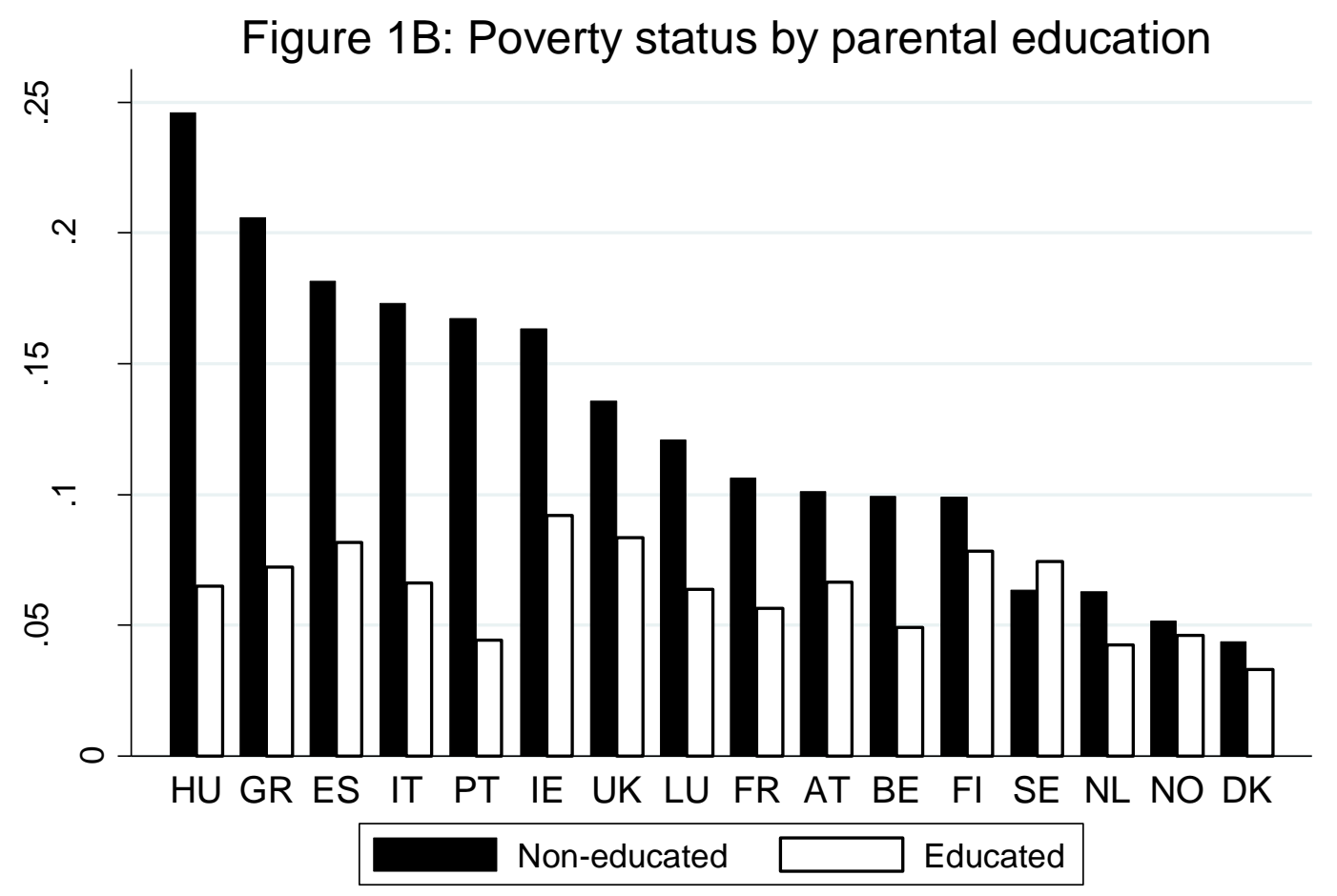

Notes: Educated parents means that at least one of them has secondary or tertiary education. Source: EUSILC, 2005 and 2011.

We find striking differences across countries. While the general pattern is that poverty rates are higher among those who have non-educated parents, the Scandinavian countries follow a different pattern. In both Denmark and Norway we cannot reject the null hypothesis that the difference in poverty rates between individuals with educated and non-educated parents is zero. Moreover, in Sweden poverty rates are higher for individuals from educated families than for those from non-educated families, and this difference is significatively different from zero. In all remaining countries poverty rates are significantly higher among those who have noneducated parents. Another clear pattern is that differences in poverty rates according to parental education are much higher in those countries where the poverty rate is high. 


\section{Separate trends for countries}

In Section 4 we present estimation results of Equation (1) where we include initial GDP and Inequality for each country-cohort and the changes in both the per capita GDP and Inequality between the time the individual was 15-17 until the year of the survey response. They control for possible changes that are happening within countries between the moment when the expenditure was made and the moment when the poverty status is determined. An additional way to account for unobserved factors consists of interacting the cohort trends with the initial GDP and the initial Inequality to allow separate trends for countries that have initially low or high productivity and inequality. We considered this possibility and obtained very similar qualitative results:

Table 1C: Overall marginal effects of public expenditure: GDP and Ineq inte racted with time trends

\begin{tabular}{|c|c|c|c|c|c|c|c|}
\hline Variables & Model 1 & Model 2 & Model 3 & Model 4 & Model 5 & Model 6 & Model 7 \\
\hline Total exp. & $\begin{array}{c}-0.0070 \\
(0.0059)\end{array}$ & & & & & & \\
\hline Exp. in compulsory education & & $\begin{array}{c}-0.0321 * * * \\
(0.0071)\end{array}$ & & & & & \\
\hline Exp. in primary education & & & $\begin{array}{c}-0.0113^{* *} \\
(0.0047)\end{array}$ & & & $\begin{array}{c}-0.0117^{* *} \\
(0.0049)\end{array}$ & $\begin{array}{c}-0.0131^{* *} \\
(0.0056)\end{array}$ \\
\hline Exp. in secondary education & & & & $\begin{array}{c}-0.0163 * * * \\
(0.0045)\end{array}$ & & $\begin{array}{c}-0.0161 * * * \\
(0.0044)\end{array}$ & $\begin{array}{c}-0.0147^{* * * *} \\
(0.0046)\end{array}$ \\
\hline Exp. in tertiary education & & & & & $\begin{array}{c}0.0043 \\
(0.0041)\end{array}$ & & $\begin{array}{l}0.0089^{*} \\
(0.0051)\end{array}$ \\
\hline Family educated & $\begin{array}{c}-0.0686^{* * * *} \\
(0.0028)\end{array}$ & $\begin{array}{c}-0.0682 * * * \\
(0.0028)\end{array}$ & $\begin{array}{c}-0.0656^{* * * *} \\
(0.0029)\end{array}$ & $\begin{array}{c}-0.0685^{* * * *} \\
(0.0028)\end{array}$ & $\begin{array}{c}-0.0674 * * * \\
(0.0027)\end{array}$ & $\begin{array}{c}-0.0685^{* * *} \\
(0.0028)\end{array}$ & $\begin{array}{c}-0.0690 * * * \\
(0.0028)\end{array}$ \\
\hline Observations & 138,512 & 139,807 & 141,701 & 140,053 & 144,349 & 139,807 & 138,512 \\
\hline
\end{tabular}

Notes: $* * * \mathrm{p}<0.01, * * \mathrm{p}<0.05, * \mathrm{p}<0.1$. Standard errors are clustered at the country -year of birth level. 


\section{Probit estimation results}

Table 1D: Overall marginal effects of public expenditure. Probit (age 15-17)

\begin{tabular}{|c|c|c|c|c|c|c|c|}
\hline I. Baseline & Model 1 & Model 2 & Model 3 & Model 4 & Model 5 & Model 6 & Model 7 \\
\hline Total exp. & $\begin{array}{c}-0.0108 * \\
(0.0061)\end{array}$ & & & & & & \\
\hline Exp. in compuls ory e ducation & & $\begin{array}{c}-0.0312 * * * \\
(0.0071)\end{array}$ & & & & & \\
\hline Exp. in primary education & & & $\begin{array}{c}-0.0154 * * * \\
(0.0054)\end{array}$ & & & $\begin{array}{c}-0.0131 * * \\
(0.0053)\end{array}$ & $\begin{array}{c}-0.0187 * * * \\
(0.0061)\end{array}$ \\
\hline Exp. in secondary education & & & & $\begin{array}{c}-0.0146 * * * \\
(0.0042)\end{array}$ & & $\begin{array}{c}-0.0146 * * * \\
(0.0041)\end{array}$ & $\begin{array}{c}-0.0198 * * * \\
(0.0043)\end{array}$ \\
\hline Exp. in tertiary education & & & & & $\begin{array}{c}0.0041 \\
(0.0043)\end{array}$ & & $\begin{array}{c}0.0127 * * * \\
(0.0049)\end{array}$ \\
\hline Family e duc ated & $\begin{array}{c}-0.0700 * * * \\
(0.0024)\end{array}$ & $\begin{array}{c}-0.0694 * * * \\
(0.0024)\end{array}$ & $\begin{array}{c}-0.0674 * * * \\
(0.0025)\end{array}$ & $\begin{array}{c}-0.0696 * * * \\
(0.0024)\end{array}$ & $\begin{array}{c}-0.0691 * * * \\
(0.0024)\end{array}$ & $\begin{array}{c}-0.0696 * * * \\
(0.0024)\end{array}$ & $\begin{array}{c}-0.0703^{* * *} \\
(0.0024)\end{array}$ \\
\hline Observations & 138,512 & 139,807 & 141,701 & 140,053 & 144,349 & 139,807 & 138,512 \\
\hline
\end{tabular}

II. Adding unemployment and its change

Total exp.

$-0.0177$

(0.0110)

Exp. in compulsory e ducation

$-0.0422 * * *$

(0.0094)

Exp. in primary education

$$
\begin{array}{r}
-0.0164 \\
(0.0105)
\end{array}
$$

$-0.0112-0.0275^{* *}$

(0.0089) (0.0107)

Exp. in secondary education

$-0.0248 * * *$ $-0.0233 * * *-0.0299 * * *$

$0.0051)$

(0.0049) (0.0052)

Exp. in tertiary education

$$
\begin{array}{cc}
0.0052 & 0.0268 * * * \\
(0.0098) & (0.0092)
\end{array}
$$

Family educated

$$
\begin{array}{cccccccc}
-0.0738 * * * & -0.0736 * * *-0.0723 * * * & -0.0742 * * * & -0.0732 * * * & -0.0743 * * * & -0.0746 * * * \\
(0.0028) & (0.0027) & (0.0028) & (0.0027) & (0.0028) & (0.0027) & (0.0028)
\end{array}
$$

Observations

82,580

83,875

$83,875 \quad 84,121$

82,826

$83,875 \quad 82,580$

Notes: $* * * \mathrm{p}<0.01, * * \mathrm{p}<0.05, * \mathrm{p}<0.1$. Standard errors are clustered at the country-year of birth level. 
Table 2D: Decomposition of the marginal effect of public expenditure. Probit

\begin{tabular}{lccccc}
\hline \hline & & & & & \\
I. Models 1-5 & Total & Compulsory & Primary & Secondary & Tertiary \\
\hline Educated family = & & & & & \\
& $-0.0277^{*} * *$ & $-0.0492^{* * *}$ & $-0.0275^{* * *}$ & $-0.0282^{* * *}$ & -0.0070 \\
Educated family $=\mathbf{1}$ & $(0.0072)$ & $(0.0086)$ & $(0.0068)$ & $(0.0048)$ & $(0.0051)$ \\
& & & & & \\
Observations & $(0.0189 * * *$ & 0.0001 & 0.0053 & $0.0088^{* *}$ & $0.0239^{*} *$ \\
\hline
\end{tabular}

\section{Model 6}

$\begin{array}{lcc}\text { Educated family = } 0 & -0.0152 * * & -0.0285^{* * *} \\ & (0.0071) & (0.0050) \\ \text { Educated family }=\mathbf{1} & -0.0096 * * & 0.0093 * * \\ & (0.0048) & (0.0047)\end{array}$

Observations

$139,807 \quad 139,807$

III. Model 7

\begin{tabular}{lccc} 
Educated family $=\mathbf{0}$ & $-0.0207 * *$ & $-0.0302 * * *$ & 0.0066 \\
& $(0.0080)$ & $(0.0053)$ & $(0.0059)$ \\
Educated family $=\mathbf{1}$ & $-0.0151^{* * *}$ & -0.0018 & $0.0233^{* * *}$ \\
& $(0.0053)$ & $(0.0058)$ & $(0.0045)$ \\
Observations & & & \\
\hline \hline
\end{tabular}

Notes: $* * * \mathrm{p}<0.01, * * \mathrm{p}<0.05, * \mathrm{p}<0.1$. Standard errors are clustered at the country-year of birth level. 


\section{E. Baseline model. Coefficients OLS}

Table 1E: Baseline models : coefficients OLS (age 15-17)

Variables

$\begin{array}{lllllll}\text { Model } 1 & \text { Model } 2 & \text { Model } 3 & \text { Model 4 } & \text { Model } 5 & \text { Model } 6 & \text { Model } 7\end{array}$

Total exp.

$$
\begin{gathered}
-0.0347 * * * \\
(0.0066) \\
0.0601 * * * \\
(0.0048)
\end{gathered}
$$

Family educated\# Total exp.

Exp. in compulsory education

$$
\begin{gathered}
-0.0510 * * * \\
(0.0076) \\
0.0513 * * * \\
(0.0056)
\end{gathered}
$$

Exp. in primary education

Family educated\# Exp. in primary education

Exp. in secondary education

Family educate d\# Exp. in secondary education

Exp. in tertiary education

Family educated\# Exp. in tertiary education

Family educated

$$
\begin{gathered}
-0.0281 * * * \\
(0.0059) \\
0.0384 * * * \\
(0.0054)
\end{gathered}
$$

$$
\begin{gathered}
-0.0322 * * * \\
(0.0041) \\
0.0448 * * * \\
(0.0047)
\end{gathered}
$$

$-0.0135^{* *}-0.0144 * *$

(0.0066) (0.0069)

$0.0025-0.0037$

$(0.0079) \quad(0.0082)$

$-0.0316 * * *-0.0303 * * *$

(0.0045) (0.0047)

$0.0431 * * * 0.0273 * * *$

(0.0067) (0.0087)

$-0.0142 * * * \quad-0.0021$

$(0.0048) \quad(0.0050)$

$0.0485 * * * \quad 0.0321 * * *$

(0.0039)

(0.0058)

$-0.2157 * * *-0.1552 * * *-0.1005 * * *-0.1158 * * *-0.1535 * * *-0.1161 * * *-0.1514 * * *$ $\begin{array}{lllllll}(0.0128) & (0.0103) & (0.0059) & (0.0063) & (0.0079) & (0.0063) & (0.0081)\end{array}$ $0.0124 * * * 0.0123 * * * 0.0122 * * * 0.0124 * * * 0.0123 * * * 0.0123 * * * 0.0124 * * *$ $\begin{array}{lllllll}(0.0019) & (0.0019) & (0.0019) & (0.0019) & (0.0019) & (0.0019) & (0.0019)\end{array}$ $0.0780 * * * 0.0617 * * * 0.0602 * * * 0.0598 * * * 0.0741 * * * 0.0612 * * * 0.0787 * * *$ $\begin{array}{lllllll}(0.0204) & (0.0181) & (0.0181) & (0.0181) & (0.0202) & (0.0181) & (0.0204)\end{array}$

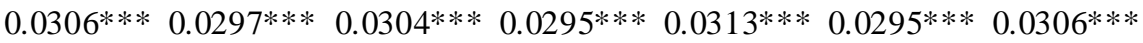

Single mother family

Number of siblings

Father unempl oyed

$(\log )$ GDP

\section{GDP growth}

Income Inequality

Change in Income Inequality

$\operatorname{cs} 2011$

\section{Constant}

$\begin{array}{cccccccc}(0.0049) & (0.0048) & (0.0049) & (0.0048) & (0.0049) & (0.0048) & (0.0049) \\ 0.0174 * * * & 0.0173 * * & 0.0172 * * * & 0.0174 * * * & 0.0175 * * * & 0.0174 * * * & 0.0175 * * * \\ (0.0010) & (0.0010) & (0.0010) & (0.0010) & (0.0010) & (0.0010) & (0.0010) \\ 0.1502 * * * & 0.1510 * * * & 0.1506 * * * & 0.1516 * * * & 0.1470 * * * & 0.1512 * * * & 0.1500 * * * \\ (0.0131) & (0.0131) & (0.0131) & (0.0131) & (0.0128) & (0.0131) & (0.0131) \\ 0.0338 & 0.0309 & 0.0336 & 0.0211 & 0.0271 & 0.0274 & 0.0442 \\ (0.0744) & (0.0736) & (0.0732) & (0.0734) & (0.0738) & (0.0734) & (0.0740) \\ -0.0106 & -0.0022 & 0.0103 & 0.0006 & -0.0009 & -0.0028 & 0.0013 \\ (0.0729) & (0.0727) & (0.0723) & (0.0726) & (0.0727) & (0.0726) & (0.0729) \\ -0.0062 & -0.0075 * & -0.0086 * & -0.0073 & -0.0093 * * & -0.0071 & -0.0090^{*} \\ (0.0047) & (0.0045) & (0.0045) & (0.0046) & (0.0045) & (0.0046) & (0.0048) \\ -0.1171 & -0.1113 & -0.1758 & -0.1122 & -0.2351 * & -0.0964 & -0.1838 \\ (0.1446) & (0.1365) & (0.1332) & (0.1362) & (0.1385) & (0.1373) & (0.1469) \\ 0.0109 * * & 0.0119 * * & 0.0130 * * * & 0.0119 * * & 0.0121 * * & 0.0117 * * & 0.0115 * * \\ (0.0048) & (0.0048) & (0.0048) & (0.0048) & (0.0048) & (0.0048) & (0.0049) \\ 0.3416 & 0.3419 & 0.2146 & 0.2848 & 0.3327 & 0.2994 & 0.2877\end{array}$




\begin{tabular}{ccccccc}
$(0.7002)$ & $(0.6984)$ & $(0.6943)$ & $(0.6993)$ & $(0.7002)$ & $(0.6982)$ & $(0.7024)$ \\
& & & & & & \\
138,512 & 139,807 & 141,701 & 140,053 & 144,349 & 139,807 & 138,512 \\
0.0380 & 0.0378 & 0.0378 & 0.0379 & 0.0379 & 0.0379 & 0.0382 \\
\hline
\end{tabular}

\begin{tabular}{lccccccc} 
Observations & 138,512 & 139,807 & 141,701 & 140,053 & 144,349 & 139,807 & 138,512 \\
R-squared & 0.0380 & 0.0378 & 0.0378 & 0.0379 & 0.0379 & 0.0379 & 0.0382 \\
\hline
\end{tabular}

Robust standard errors in parentheses

$* * * \mathrm{p}<0.01, * * \mathrm{p}<0.05, * \mathrm{p}<0.1$ 


\section{F. Robustness analysis}

In this section we study the robustness of our analysis incorporating additional regressors and using alternative definitions of parental background and current poverty status.

\section{Country income and initial inequality}

We check whether public expenditure has a similar impact on poverty reduction regardless of some contextual variables as country GDP or inequality. The idea is that, in the same way as the effect of public expenditure depends on family type, the effect of GDP and inequality on adult poverty may also depend on the level of education in the family. In order to do so, we modify Equation (1) including two additional interaction terms of expenditure: one with the variable $G D P_{c t}$ and another one with the variable $I N E Q_{c t}$. Table $1 \mathrm{G}$ below shows the average marginal effects corresponding to the variables of interest: public expenditure and parental education. The first panel of Table $1 \mathrm{G}$ shows the results of Equation (1) where, in addition, $P E_{c t}$ is interacted with $G D P_{c t}$ for our Models 1 to 7 (see Table 3). The second panel of Table $1 \mathrm{G}$ shows the results for the same seven measures of public expenditure for a model where $P E_{c t}$ is interacted with $I N E Q_{c t}$. Finally the bottom panel of Table 6 shows the results for a specification which contains interactions of $P E_{c t}$ with both $G D P_{c t}$ and $I N E Q_{c t}$. The results we get are similar to those in Table 3.

\section{Table 1G: Differential impact of PE by country GDP and Inequality}

\begin{tabular}{|c|c|c|c|c|c|c|c|}
\hline $\begin{array}{l}\text { I. Interaction PE } \\
\text { and GDP }\end{array}$ & Model 1 & Model 2 & Model 3 & Model 4 & Model 5 & Model 6 & Model 7 \\
\hline Total exp. & $\begin{array}{l}-0.0123^{*} \\
(0.0066)\end{array}$ & & & & & & \\
\hline $\begin{array}{l}\text { Exp. in compulsory } \\
\text { educ }\end{array}$ & & $\begin{array}{c}-0.0327 * * * \\
(0.0071)\end{array}$ & & & & & \\
\hline $\begin{array}{l}\text { Exp. in primary } \\
\text { educ }\end{array}$ & & & $\begin{array}{c}-0.0139 * * * \\
(0.0053)\end{array}$ & & & $\begin{array}{c}-0.0130^{* *} \\
(0.0056)\end{array}$ & $\begin{array}{c}-0.0166 * * * \\
(0.0063)\end{array}$ \\
\hline $\begin{array}{l}\text { Exp. in secondary } \\
\text { educ }\end{array}$ & & & & $\begin{array}{c}-0.0170 * * * \\
(0.0043)\end{array}$ & & $\begin{array}{c}-0.0160 * * * \\
(0.0042)\end{array}$ & $\begin{array}{c}-0.0197 * * * \\
(0.0044)\end{array}$ \\
\hline Exp. in tertiary educ & & & & & $\begin{array}{l}0.0035 \\
(0.0047)\end{array}$ & & $\begin{array}{c}0.0097 * * \\
(0.0048)\end{array}$ \\
\hline Family e ducated & $\begin{array}{c}-0.0688 * * * \\
(0.0028)\end{array}$ & $\begin{array}{c}-0.0684 * * * \\
(0.0028)\end{array}$ & $\begin{array}{c}-0.0657 * * * \\
(0.0029)\end{array}$ & $\begin{array}{c}-0.0688^{* * * *} \\
(0.0028)\end{array}$ & $\begin{array}{c}-0.0675^{* * * *} \\
(0.0027)\end{array}$ & $\begin{array}{c}-0.0687 * * * \\
(0.0028)\end{array}$ & $\begin{array}{c}-0.0694 * * * \\
(0.0027)\end{array}$ \\
\hline
\end{tabular}

II. Inter action PE and Inequality

Total exp.

$-0.0120^{*}$ 
Exp. in compulsory

educ

Exp. in primary

educ

Exp. in secondary

educ

Exp. in tertiary educ

Family educated
$(0.0066)$

$$
\begin{gathered}
-0.0323 * * * \\
(0.0067)
\end{gathered}
$$

\begin{tabular}{ccccc}
$-0.0142 * * *$ & & $-0.0122 * *$ & $-0.0126 * *$ \\
$(0.0051)$ & & & $(0.0051)$ & $(0.0058)$ \\
& & & $-0.0165^{* * *}$ & $-0.0227 * * *$ \\
& $-0.0154 * * *$ & & $(0.0039)$ & $(0.0042)$ \\
& $(0.0041)$ & & & 0.0073 \\
& & 0.0034 & & $(0.0053)$ \\
$-0.0657 * * *$ & $-0.0687 * * *$ & $-0.0676 * * *$ & $-0.0687 * * *$ & $-0.0695 * * *$ \\
$(0.0029)$ & $(0.0028)$ & $(0.0027)$ & $(0.0028)$ & $(0.0027)$ \\
\hline & & & &
\end{tabular}

III. Interaction PE with both GDP and

\begin{tabular}{|c|c|c|c|c|c|c|c|}
\hline Total exp. & $\begin{array}{l}-0.0120 * \\
(0.0066)\end{array}$ & & & & & & \\
\hline $\begin{array}{l}\text { Exp. in compuls ory } \\
\text { educ }\end{array}$ & & $\begin{array}{c}-0.0322 * * * \\
(0.0066)\end{array}$ & & & & & \\
\hline $\begin{array}{l}\text { Exp. in primary } \\
\text { educ }\end{array}$ & & & $\begin{array}{c}-0.0141 * * * \\
(0.0051)\end{array}$ & & & $\begin{array}{c}-0.0118^{* *} \\
(0.0054)\end{array}$ & $\begin{array}{c}-0.0151 * * \\
(0.0062)\end{array}$ \\
\hline $\begin{array}{l}\text { Exp. in secondary } \\
\text { educ }\end{array}$ & & & & $\begin{array}{c}-0.0169 * * * \\
(0.0044)\end{array}$ & & $\begin{array}{c}-0.0168 * * * \\
(0.0043)\end{array}$ & $\begin{array}{c}-0.0229 * * * \\
(0.0043)\end{array}$ \\
\hline Exp. in tertiary educ & & & & & $\begin{array}{c}0.0033 \\
(0.0047)\end{array}$ & & $\begin{array}{c}0.0061 \\
(0.0050)\end{array}$ \\
\hline Family educated & $\begin{array}{c}-0.0689 * * * \\
(0.0028)\end{array}$ & $\begin{array}{c}-0.0684 * * * \\
(0.0028)\end{array}$ & $\begin{array}{c}-0.0657 * * * \\
(0.0029)\end{array}$ & $\begin{array}{c}-0.0688 * * * \\
(0.0028)\end{array}$ & $\begin{array}{c}-0.0676^{* * *} * \\
(0.0027)\end{array}$ & $\begin{array}{c}-0.0687 * * * \\
(0.0028)\end{array}$ & $\begin{array}{c}-0.0695^{* * *} * \\
(0.0027)\end{array}$ \\
\hline Observations & 138,512 & 139,807 & 141,701 & 140,053 & 144,349 & 139,807 & 138,512 \\
\hline
\end{tabular}
Inequality Notes: $* * * \mathrm{p}<0.01, * * \mathrm{p}<0.05, * \mathrm{p}<0.1$. Standard errors are clustered at the country-year of birth level. Public expenditure at age $15-17$.

\section{Parental background}

Here we check the robustness of our results to alternative measures of parental background. In particular, we use the information provided by individuals about the economic situation in the household: whether parental household had financial difficulties while the individual was a teenager. ${ }^{1}$

\footnotetext{
${ }^{1}$ We decided not to use this variable in the main specification of the model for three reasons. First, this variable does not take the same categorical values in the two cross sections. Second, this variable is missing in four countries in the 2005 cross section (Austria, France, Greece and Portugal), reducing considerably sample size. Third, this variable can be seen as a very subjective indicator. Nonetheless, we use this variable to check the validity of our results to altern ative measures of childhood circu mstances.
} 
Individuals were asked how frequent financial problems in the household were when they were young teenagers. In the 2005 cross section there are five possible answers: 1 (most of the time), 2 (often), 3 (occasionally), 4 (rarely), and 5 (never). In the 2011 cross section there are six possible answers: 1 (very bad), 2 (bad), 3 (moderately bad), 4 (moderately good), 5 (good), and 6 (very good). We summarized the information of these questions by constructing a dummy variable called "poor_past" that takes value 1 when the corresponding variable is either 1 or 2 in the 2005 cross section and when it is 1, 2, or 3 in the 2011 cross section. By doing so, we obtain comparable frequencies in the two cross sections.

In the upper part of Table $2 \mathrm{G}$ we present the results of estimating Equation (1), dropping the variable EDFAM from the list of regressors, and replacing it with poorpast, which serves as an alternative description of parental background. We also include an interaction term between public expenditure and poor_past. We lose some observations from the 2005 wave since four countries do not report this variable in that wave (Austria, France, Greece, and Portugal). We check whether our results change when considering both parental education and past poverty status. The results of these estimations are shown in the bottom part of Table 2G.

Table 2G: Alternative measures of parental background

I. Poor family

$\begin{array}{lllllll}\text { Model 1 } & \text { Model 2 } & \text { Model 3 } & \text { Model 4 } & \text { Model } 5 & \text { Model 6 } & \text { Model 7 }\end{array}$

Total exp. $\quad-0.0211 * * *$

$(0.0070)$

Exp. in compulsory educ

$-0.0395 * * *$

(0.0077)

Exp. in primary educ

$-0.0138 * *$

$-0.0163 * * *-0.0189 * * *$

(0.0053)

(0.0057) (0.0059)

Exp. in secondary educ

$-0.0210 * * * \quad-0.0210 * * *-0.0242 * * *$

(0.0043)

(0.0043) (0.0044)

Exp. in tertiary educ

$\begin{array}{cccccccc} & & & & & -0.0009 & & 0.0081 \\ & & & & (0.0049) & & (0.0052) \\ 0.0524 * * * & 0.0531 * * * & 0.0528 * * * & 0.0537 * * * & 0.0524 * * * & 0.0531 * * * & 0.0525 * * * \\ (0.0032) & (0.0032) & (0.0032) & (0.0031) & (0.0030) & (0.0033) & (0.0031)\end{array}$

Family poor

(0.0032) (0.0032)

127,794

$126,134 \quad 130,435$

125,886

124,582

$\underline{\text { II. Poor family and educated family }}$

Total exp. $\quad-0.0176^{* *}$

Exp. in compulsory educ

(0.0071)

Exp. in primary educ

$-0.0371 * * *$

(0.0078)

Exp. in secondary educ

$-0.0140^{* *}$

$-0.0139 * *-0.0160 * * *$

(0.0055)

(0.0056) (0.0058)

Exp. in tertiary educ

$-0.0188 * * *$

$-0.0195 * * *-0.0238 * * *$

(0.0042)

(0.0042)

(0.0045)

0.0020

0.0082

(0.0048)

(0.0050) 


$\begin{array}{lccccccc}\text { Family poor } & 0.0382 * * * & 0.0387 * * * & 0.0387 * * * & 0.0388 * * * & 0.0381 * * * & 0.0388 * * * & 0.0383 * * * \\ \text { Family educated } & (0.0027) & (0.0027) & (0.0027) & (0.0027) & (0.0026) & (0.0027) & (0.0027) \\ & -0.0673 * * * & -0.0662 * * * & -0.0634 * * * & -0.0671 * * * & -0.0665 * * * & -0.0663 * * * & -0.0673 * * * \\ & (0.0029) & (0.0030) & (0.0030) & (0.0029) & (0.0028) & (0.0029) & (0.0028)\end{array}$

Observations

$\begin{array}{lllllll}122,075 & 123,367 & 125,251 & 123,613 & 127,902 & 123,367 & 122,075\end{array}$

Notes: $* * * \mathrm{p}<0.01, * * \mathrm{p}<0.05, * \mathrm{p}<0.1$. Standard errors are clustered at the country-year of birth level. Public expenditure at age 15-17. The specification in panel is the one proposed in Equation (1) but substituting the variable educated_family for poor_past. The specification in panel II is the one proposed in Equation (1) but adding the poor_past variable to the interaction between PE and educated_family.

Results are in line with the ones obtained us ing only parental education (see Table 3). Public expenditure is strongly associated with poverty reduction. Since the models we estimate contain an interaction term between expenditure and family type, we can compute marginal effects separately according to family type. This is what Table $3 \mathrm{G}$ shows, for the model that only includes poor_past instead of EDFAM. Similar to Table 4 above, in the upper part of the table we present the results corresponding to Mode ls 1-5. Below we present the results corresponding to Models 6 and 7.

Table 3G: Decomposition of the marginal effect of public expenditure

\begin{tabular}{|c|c|c|c|c|c|}
\hline I. Models 1-5 & Total & Compulsory & Primary & Secondary & Tertiary \\
\hline Poor family $=0$ & $\begin{array}{l}-0.0134 * \\
(0.0071)\end{array}$ & $\begin{array}{c}-0.0355^{* * *} * \\
(0.0078)\end{array}$ & $\begin{array}{l}-0.0090 * \\
(0.0054)\end{array}$ & $\begin{array}{c}-0.0185^{* * *} * \\
(0.0045)\end{array}$ & $\begin{array}{c}0.0072 \\
(0.0051)\end{array}$ \\
\hline Poor family $=1$ & $\begin{array}{c}-0.0461 * * * \\
(0.0091)\end{array}$ & $\begin{array}{c}-0.0527 * * * \\
(0.0094)\end{array}$ & $\begin{array}{c}-0.0294 * * * \\
(0.0079)\end{array}$ & $\begin{array}{c}-0.0292 * * * \\
(0.0059)\end{array}$ & $\begin{array}{c}-0.0266^{* * *} \\
(0.0069)\end{array}$ \\
\hline Observations & 124,582 & 125,886 & 127,794 & 126,134 & 130,435 \\
\hline II. Model 6 & & & & & \\
\hline Poor family $=0$ & & & $\begin{array}{c}-0.0129 * * \\
(0.0058)\end{array}$ & $\begin{array}{c}-0.0203^{* * *} * \\
(0.0045)\end{array}$ & \\
\hline Poor family = 1 & & & $\begin{array}{c}-0.0276^{* * *} \\
(0.0094)\end{array}$ & $\begin{array}{c}-0.0233^{* * *} * \\
(0.0069)\end{array}$ & \\
\hline Observations & & & 125,886 & 125,886 & \\
\hline
\end{tabular}

III. Model 7

Poor family $=0$

$\begin{array}{ccc}-0.0180 * * * & -0.0277 * * * & 0.0181 * * * \\ (0.0063) & (0.0048) & (0.0053)\end{array}$


Note: $* * * \mathrm{p}<0.01, * * \mathrm{p}<0.05, * \mathrm{p}<0.1$. Standard errors are clustered at the country-year of birth level. Public expenditure at age $15-17$.

When we disaggregate the effect of expenditure by family type, we find that the negative association between public expenditure and poverty for individuals from poor families is stronger, in general, than the corresponding association for individuals from non-poor families.

Finally, we try an alternative definition of parental background by not categorizing as poor those individuals in the 2011 cross section who answered that family situation was "moderately bad". This means that we consider that only those individuals for which the corresponding variable is either 1 or 2 were poor. That is, now we present results defining the variable poor_past which takes value 1 when the corresponding variable in 2005 and 2011 is equal to 1 or 2 :

Table 4G: Alternative past poverty definition

\begin{tabular}{|c|c|c|c|c|c|c|c|}
\hline I. Poor family & Model 1 & Model 2 & Model 3 & Model 4 & Model 5 & Model 6 & Model 7 \\
\hline Total exp. & $\begin{array}{c}-0.0205 * * * \\
(0.0071)\end{array}$ & & & & & & \\
\hline Exp. in compulsory e ducation & & $\begin{array}{c}-0.0397 * * * \\
(0.0077)\end{array}$ & & & & & \\
\hline Exp. in primary education & & & $\begin{array}{c}-0.0140 * * * \\
(0.0054)\end{array}$ & & & $\begin{array}{c}-0.0166 * * * \\
(0.0057)\end{array}$ & $\begin{array}{c}-0.0188^{* * * *} \\
(0.0059)\end{array}$ \\
\hline Exp. in secondary education & & & & $\begin{array}{c}-0.0205^{* * * *} \\
(0.0043)\end{array}$ & & $\begin{array}{c}-0.0209 * * * \\
(0.0042)\end{array}$ & $\begin{array}{c}-0.0238^{* * * *} \\
(0.0044)\end{array}$ \\
\hline Exp. in tertiary education & & & & & $\begin{array}{c}-0.0004 \\
(0.0050)\end{array}$ & & $\begin{array}{c}0.0083 \\
(0.0053)\end{array}$ \\
\hline Family poor & $\begin{array}{c}0.0611^{* * *} * \\
(0.0037)\end{array}$ & $\begin{array}{c}0.0623 * * * \\
(0.0038)\end{array}$ & $\begin{array}{c}0.0627^{* * *} \\
(0.0039)\end{array}$ & $\begin{array}{c}0.0628^{* * * *} \\
(0.0037)\end{array}$ & $\begin{array}{c}0.0608 * * * \\
(0.0036)\end{array}$ & $\begin{array}{c}0.0627 * * * \\
(0.0038)\end{array}$ & $\begin{array}{c}0.0621 * * * \\
(0.0037)\end{array}$ \\
\hline Observations & 124,582 & 125,886 & 127,794 & 126,134 & 130,435 & 125,886 & 124,582 \\
\hline
\end{tabular}

\section{Poor family and educated family}

$\begin{array}{lcccc}\text { Total exp. } & -0.0166^{* *} & & \\ & (0.0071) & & \\ \text { Exp. in compulsory education } & -0.0363^{* * *} & & \\ & (0.0078) & -0.0136^{* *} & -0.0156^{* * *} \\ \text { Exp. in primary education } & & -0.0139 * * & (0.0057) & (0.0059)\end{array}$


Family poor

Family educ ated

\section{Observations}

$122,075 \quad 123,367$

125,251

\begin{tabular}{llll}
123,613 & 127,902 & 123,367 & 122,075 \\
\hline
\end{tabular}

Notes: $* * * \mathrm{p}<0.01, * * \mathrm{p}<0.05, * \mathrm{p}<0.1$. Standard errors are clustered at the country-year of birth level. The specification in panel I is the one proposed in Equation (1) but substituting the variable educated_family for poor_past. The specification in panel II is the one proposed in Equation (1) but adding the poor_past variable to the interaction between PE and educated_family.

As can be observed, the result is robust to this new definition of poor family.

One interesting implication of our analysis so far is as follows. Higher levels of public expenditure reduce on average the probability of being poor when adult. Additionally, being raised in a non-poor household also reduces the probability of being poor when adult. Then, the impact of public expenditure gets amplified in the long-run. Spending more money in today's children will make less likely that these kids will be poor when adults. This, in turn, will reduce the probability of being poor for next generation's children. ${ }^{2}$

\section{Poverty measure}

Here we check the robustness of our results to alternative definitions of poverty. The poverty measure used in the main part of the paper (variable HX080 in the EU-SILC database) uses disposable household income (variable HY020). In particular, the poverty indicator takes value one if the equivalized disposable household income is below $60 \%$ of median equivalized household disposable income. This is the official measure of poverty in the European Union. Disposable household income is the sum of market income plus social transfers minus taxes and social security contributions. Here we consider two alternative definitions of poverty in which we exclude some social transfers from household disposable income. We do this to avoid the impact of current redistributive policies on poverty status. Social transfers cause some individuals to be above the poverty threshold. If we do not take this account we may attribute to past public expenditure an effect that is just re lated to current public transfers and therefore we would be overestimating the impact of past public expenditure.

Our first alternative measure (gross poverty A) excludes most social transfers, in particular, unemployment benefits, sickness benefits, disability benefits, education-related allowances, family/children related allowances, social exclusion not elsewhere classified and housing

\footnotetext{
${ }^{2}$ It can be check that individuals with non-educated parents are indeed differentially poorer: among individuals with non-educated parents almost $21 \%$ were poor when teenager (poor_past=1) whereas it is only $7.47 \%$ among individuals with educated-parents.
} 
allowances. However it retains old-age benefits and survivor' benefits. ${ }^{3}$ Our second alternative (gross-poverty B) is similar to the previous one, but including also unemployment benefits. ${ }^{4}$ That is, it is an intermediate measure between the previous two ones. The results of estimating Equation (1) for Models 1-7 using these two alternative poverty definitions are shown in Table $5 \mathrm{G}$.

Table 5G: Overall marginal effects of public expenditure: Gross Poverty

\section{Gross Poverty}

\section{A} Model 1 Model 2 Model 3 Model 4 Model 5 Model 6 Model 7

0.0064
Total exp.

Exp. in compulsory educ

Exp. in primary educ

Exp. in secondary educ

Exp. in tertiary educ

Family educated
$-0.0208^{* *}$

$(0.0094)$
$-0.0152 * *$

(0.0069)
$-0.0131 * \quad-0.0216^{* * *}$

$(0.0073) \quad(0.0073)$

$-0.0095-0.0095-0.0171 * * *$

(0.0058)

$(0.0058)$

$\begin{array}{ccccccc}-0.1138 * * * & -0.1130 * * * & -0.1102 * * * & -0.1132 * * * & -0.1123 * * * & -0.1132 * * * & -0.1139 * * * \\ (0.0032) & (0.0032) & (0.0033) & (0.0031) & (0.0031) & (0.0032) & (0.0031)\end{array}$

Observations $138,536 \quad 139,831$ 141,725 140,077 144,373 139,831 138,536

\section{Gross Poverty}

B

$\begin{array}{lr}\text { Total exp. } & 0.0045 \\ & (0.0082)\end{array}$

Exp. in

compuls ory educ

$-0.0217 * *$

Exp. in primary

(0.0090)

educ

$-0.0122 *$

(0.0067)

Exp. in secondary educ

\section{$0.0082)$}

\footnotetext{
${ }^{3}$ Our new measure of equivalized dis posable household income is equal to the product of total disposable household income before social transfers other than old-age and survivor's benefits (HY022), multiplied by an inflation factor for within-household non-response (HY025), divided by equivalized household size (HX050). That is, ((HY022*HY025)/(HX050)).

${ }^{4}$ Total disposable income now is equal to HY022 plus unemployment benefits (PY090G). In order to have the same number of missing observations in the Gross Poverty B and our poverty measure we redefine PY090G to be equal to 0 when missing.
} 
Exp. in tertiary

educ

(0.0056)

(0.0056)

(0.0059)

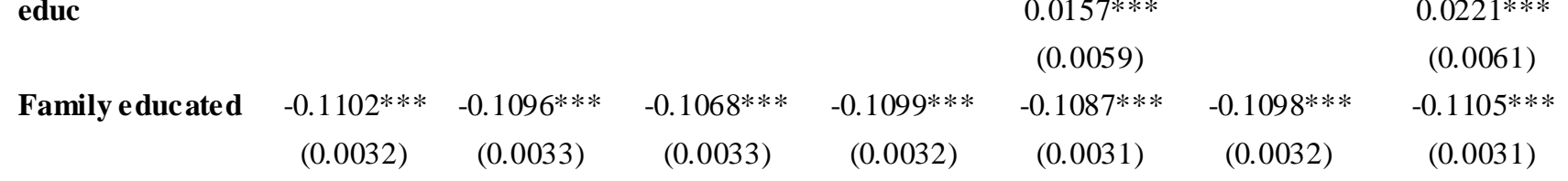

$\begin{array}{llllllll}\text { Observations } & 138,536 & 139,831 & 141,725 & 140,077 & 144,373 & 139,831 & 138,536\end{array}$

Notes: $* * * \mathrm{p}<0.01, * * \mathrm{p}<0.05, * \mathrm{p}<0.1$. Standard errors are clustered at the country -year of birth level. Public expenditure at age $15-17$.

In Table 6G we decompose the marginal effect of public expenditure on gross poverty A for individuals with educated and non-educated parents.

Table 6G: Decomposition of the marginal effect of public expenditure

\begin{tabular}{|c|c|c|c|c|c|}
\hline I. Models 1-5 & Total & Compulsory & Primary & Secondary & Tertiary \\
\hline Educated family $=0$ & $\begin{array}{l}-0.0161 * \\
(0.0085)\end{array}$ & $\begin{array}{c}-0.0383 * * * \\
(0.0095)\end{array}$ & $\begin{array}{c}-0.0295 * * * \\
(0.0072)\end{array}$ & $\begin{array}{c}-0.0245 * * * \\
(0.0061)\end{array}$ & $\begin{array}{l}-0.0014 \\
(0.0062)\end{array}$ \\
\hline Educated family $=1$ & $\begin{array}{c}0.0456 * * * \\
(0.0098)\end{array}$ & $\begin{array}{c}0.0094 \\
(0.0107)\end{array}$ & $\begin{array}{c}0.0092 \\
(0.0081)\end{array}$ & $\begin{array}{c}0.0164 * * \\
(0.0066)\end{array}$ & $\begin{array}{c}0.0511 * * * \\
(0.0072)\end{array}$ \\
\hline Observations & 138,536 & 139,831 & 141,725 & 140,077 & 144,373 \\
\hline II. Model 6 & & & & & \\
\hline Educated family $=0$ & & & $\begin{array}{c}-0.0149 * \\
(0.0085)\end{array}$ & $\begin{array}{c}-0.0233 * * * \\
(0.0066)\end{array}$ & \\
\hline Educated family $=1$ & & & $\begin{array}{l}-0.0098 \\
(0.0083)\end{array}$ & $\begin{array}{c}0.0144 * * \\
(0.0070)\end{array}$ & \\
\hline Observations & & & 139,831 & 139,831 & \\
\hline
\end{tabular}

III. Model 7

Educated family $=0$

Educated family $=1$

$\begin{array}{ccc}-0.0212 * * & -0.0236 * * * & 0.0100 \\ (0.0087) & (0.0069) & (0.0066) \\ -0.0224 * * * & -0.0057 & 0.0497 * * * \\ (0.0081) & (0.0082) & (0.0079)\end{array}$


Notes: $* * * \mathrm{p}<0.01, * * \mathrm{p}<0.05, * \mathrm{p}<0.1$. Standard errors are clustered at the country-year of birth level. Public expenditure at age $15-17$.

Again we find a strong association between public expenditure and poverty reduction, mostly for individuals from poor parental backgrounds. To conclude, the impact of public expenditure on poverty reduction is robust to whether current poverty status is measured before or after current social transfers. In other words, there is no evidence that we are overestimating the impact of past public expenditure.

\section{Place bo tre atment}

In this final robustness check of the paper, we perform a falsification exercise. In our main specification (Models 1-7) we have analyzed the effect of public expenditure when the individual was $15-17$ on adult poverty. What we propose to do here is to regress poverty rates in adulthood on public expenditure from a different period than the one we are considering in our main specification. In particular, to each cohort from a given country, we randomly assign public expenditure corresponding to a different cohort from the same country. As an example, consider the cohort of individuals born in Austria in 1970. In our main specification we assign to these individuals the average of public expenditure in the years 1985-87. What we do now is to assign them a different expenditure level chosen randomly from all the expenditure levels from the different cohorts in Austria. Once we do this, we estimate again Equation (1) with this new measure of public expenditure. We repeat this exercise one hundred times. If the results in Section 4 were just spurious correlations, the result of this falsification exercise should have little impact on them. We have done this exercise only for public expenditure in secondary education, our Model 4. Recall that the marginal effect we obtained (see Table 3) was -0.0158 . In Figure 4 below we show a histogram of the t-statistics corresponding to the one hundred regressions in which we reshuffle the values of public expenditure in secondary education. Only in four cases out of 100 we get a value of the t-statistic below -2, while in 9 cases we get a value above 2. That is, only in 4 cases we obtain a value of the coefficient of interest that is negative and statistically significant. In 9 out of 100 we get a value that is positive and statistically significant, while in 87 out of 100 repetitions the coefficient of interest is not statistically different from zero. For the sake of comparison, we also estimate the coefficient of the dummy variable $E D F A M_{i}$. In all the 100 repetitions the coefficient of this variable is negative and statistically significant. In fact, it changes almost nothing since the lowest value we estimate is .0676 and the highest is -.0659 . 
Figure 1F: Histogram of t-statistics of 100 repetitions

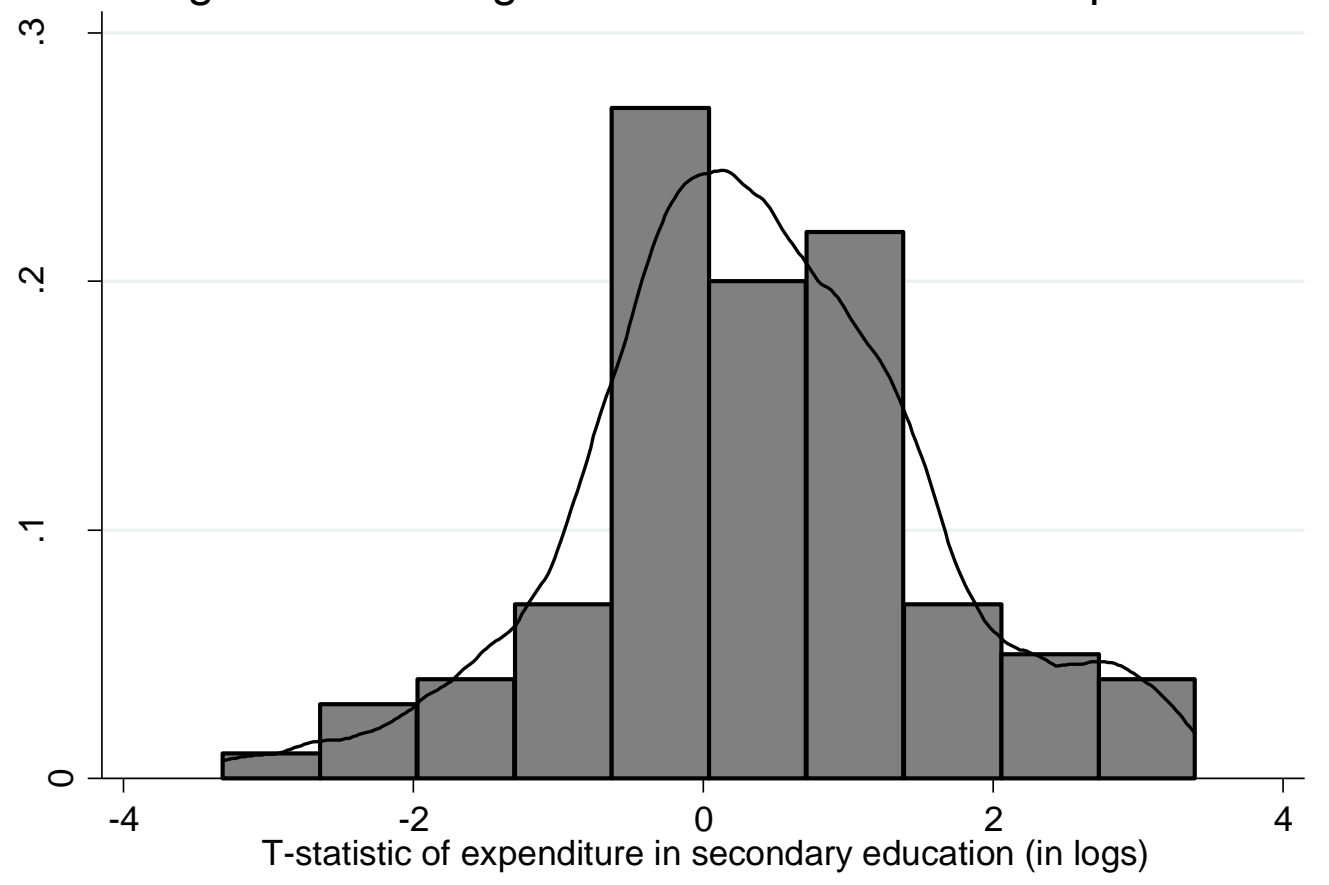

As can be observed, even though the impact of family education remains significant in all cases, the effect of public expenditure is not significant in most cases. These results indicate that the actual measures of public expenditure are meaningful determinants of the variation of current poverty rates among individuals. 